\title{
An Extensive Collection of Evaluation Indicators to Assess Occupants' Health and Comfort in Indoor Environment
}

\author{
Fabio Fantozzi ${ }^{(\mathbb{D})}$ and Michele Rocca $*$ iD \\ Department of Energy, Systems, Territory and Constructions Engineering, University of Pisa, 56122 Pisa, Italy; \\ f.fantozzi@ing.unipi.it \\ * Correspondence: michele.rocca.au@gmail.com; Tel.: +39-050-221-7104
}

Received: 26 November 2019; Accepted: 4 January 2020; Published: 12 January 2020

\begin{abstract}
Today, the effects of the indoor environment on occupants' health and comfort represent a very important topic and requires a holistic approach in which the four main environmental factors (thermal comfort, air quality, acoustics, and lighting) should be simultaneously assessed. The present paper shows the results of a literature survey that aimed to collect the indicators for the evaluation of occupants' health and comfort in indoor environmental quality evaluations. A broad number of papers that propose the indicators of a specific environmental factor is available in the scientific literature, but a review that collects the indicators of all four factors is lacking. In this review paper, the difference between indicators for the evaluation of risk for human health and for comfort evaluation is clarified. For each environmental factor, the risk for human health indicators are proposed with the relative threshold values, and the human comfort indicators are grouped into categories according to the number of parameters included, or the specific field of application for which they are proposed. Furthermore, the differences between human health and comfort indicators are highlighted.
\end{abstract}

Keywords: health and comfort; evaluation indicators; work environments; indoor environmental quality; indoor comfort; human health

\section{Introduction}

Nowadays, the awareness of the relevance of obtaining buildings with high performance to reduce both energy consumption and the impact on the environment $\left(\mathrm{CO}_{2}\right.$ emissions into the atmosphere), have been collectively reached. The challenge is now to guarantee a high level of housing quality while maintaining low energy consumption. People spend almost $90 \%$ of their life in indoor environments (houses, schools, work environments, etc.) and the effects of indoor conditions on human health cannot be ignored. The interest in buildings that guarantee high levels of occupant health is increasing both in research and in professional practice. In different areas (i.e., health, economy, etc.), comfort, well-being, and quality of life are becoming increasingly important [1,2]. The built environment can be interpreted as a physical and social environment that must guarantee the environmental conditions to promote wellbeing, health, productivity, and interactions between people. To this aim, at the European level, new building certification assets have already been developed; they include not only the assessment of energy performance, but also the levels of comfort and well-being that can be achieved within the indoor environment [3-6]. Health is defined by the World Health Organization (WHO) as "a state of complete physical, mental, and social well-being and not merely the absence of disease or infirmity" [7]. Corresponding to this definition, there is a change of the public health focus from life expectancy to health expectancy, which no longer includes mortality in favor of aspects of quality of life [8,9]. 
Indoor environmental quality (IEQ) assessments, with particular reference to work environments, should combine the evaluation of all the possible factors that can have negative effects on health with the evaluation of the perceived levels of comfort [10]. New holistic approaches in which building energy performance is combined with the indoor environmental conditions, are increasingly used [11-14].

The health risks evaluation is generally carried out using "pass/fail criteria" purely quantitative that generally involve comparisons between the measured or calculated parameters and the related limits (threshold values).

The comfort evaluation includes quantitative, qualitative, and subjective investigations. In this field, the human perception is particularly relevant and cannot be neglected. Comfort assessment is generally performed through the evaluation of the IEQ, that is based on four environmental factors that simultaneously affect the human perception, namely: thermal environment, indoor air quality, acoustical environment, and visual environment [1,15-18].

Concerning the effects of the indoor environment on human health, in addition to the building-related illnesses caused by specific exposures in indoor environments (e.g., rhinitis, asthma, and hypersensitivity pneumonitis, etc.), sick building syndrome (SBS) consists of a group of mucosal, skin, and general symptoms that are temporally related to working in particular buildings $[19,20]$. The SBS is characterized by "non-specific" effects and its signs can be highly variable, affecting diverse parts of the human body, and correlating them to SBS could be challenging in the first place [21]. The SBS was introduced the first time by the WHO in 1983 [22], and it is well demonstrated that sick buildings can also induce stress, anxiety, and aggression [23,24]. These negative effects can further result in an increase in the possibility of hazardous events in workplaces [21].

Another important point is the selection of evaluation indicators. There are numerous indicators in the scientific literature, but the distinction between health and comfort indicators is not always clear. Concerning the thermal environment among the huge amount of indicators proposed in the literature, only five are normalized: Wet Bulb Globe Temperature (WBGT), required clothing insulation (IREQ), Predicted Heat Strain (PHS), and Predicted Mean Vote (PMV) and Predicted Percentage of Dissatisfied (PPD) for the thermal comfort $[25,26]$. On the contrary, concerning the visual environment, specific indicators for the assessment of the risk arising from a non-adequate lighting exposure do not exist, and the same indicators are used for both visual comfort and improper light exposure assessments. Moreover, only some indicators (e.g., PMV, PPD, etc.) can be used alone because they combine different physical parameters and provide overall information on the human perception of a specific environmental factor. The other indicators (e.g., illuminance, reverberation time, etc.) provide detailed information and it is necessary to combine the results of more indicators to obtain an overall evaluation on environmental factor.

In the literature, articles are available that collect indicators of individual environmental factors (i.e., [27-31]); however, there is no review to collect indicators of multiple environmental factors. For this reason, and given the growing interest in overall assessments, the authors decided to collect the indicators of all four main IEQ environmental factors: thermal environment, indoor air quality, acoustics and lighting. The objective of this paper is to create a comprehensive overview of indicators for assessing human health and comfort in the indoor environment. This collection could also be a useful starting point for those who must approach global assessments of the indoor environment. The present paper is composed of a first section on health and comfort evaluations where some general indications are provided, four further sections, one for each main environmental factor, and the conclusive remarks. The four sections on the environmental factors are developed following the same structure. The first part is related to the risk for human health evaluation and it is composed of an "Overview", a framework of "Guideline and legislative outline", and a collection of the "Indicators". The second part is related to the comfort aspects and it is composed of an "Overview", a collection of "Indicators", and some information on the "Current research trends". For both risk and comfort, the most commonly used indicators are briefly described, and the main aspects discussed. With regard to the risk assessment for human health, together with the most important risk indicators, the reference 
limit values (minimum/threshold values) that must be guarantee at international level are reported. As regards the assessment of comfort, the indicators are grouped into categories according to the number of parameters included, or the specific field of application for which they were proposed.

\section{Literature Search}

The literature research started by separately search in the scientific databases "ScienceDirect", "MDPI", "Web of Science" (WOS) and "Google Scholar" the terms related to health and comfort evaluation of the four main environmental factors: "thermal comfort", "thermal stress" "indoor air quality", "indoor air pollution", acoustics comfort", "noise exposure", "visual comfort", "visual fatigue". The summary of the results of this search are reported in Table 1. It is possible to observe that "thermal comfort" and "indoor air quality" are the most studied topics, while "acoustic comfort" is the subject on which it was less published. However, it should be considered that, although the terms "thermal comfort" and "indoor air quality" are the specific terms uniquely used to refer to the relative factor, "visual comfort" and "acoustic comfort" are not always the only terms used. In fact, the term "acoustic comfort" is sometimes replaced by "aural comfort" or "sound quality".

Table 1. Results of general literature search in different scientific databases.

\begin{tabular}{|c|c|c|c|c|}
\hline & Google Scholar & Science Direct & WOS & MDPI \\
\hline Search in & $\begin{array}{c}\text { All } \\
\text { (not optional) }\end{array}$ & $\begin{array}{l}\text { Title, abstract, } \\
\text { keywords }\end{array}$ & $\begin{array}{l}\text { Title, abstract, } \\
\text { keywords }\end{array}$ & Title, keywords \\
\hline Sort type & $\begin{array}{c}\text { Relevance } \\
\text { (not optional) }\end{array}$ & Relevance & Time cited & Time cited \\
\hline Meaning of classification & $\begin{array}{l}\text { Publisher, authors, } \\
\text { number of citations, } \\
\text { recent citations }\end{array}$ & $\begin{array}{l}\text { Highest occurrence } \\
\text { of search item }\end{array}$ & $\begin{array}{l}\text { Highest number of } \\
\text { citation }\end{array}$ & $\begin{array}{l}\text { Highest number of } \\
\text { citation }\end{array}$ \\
\hline keywords & \multicolumn{4}{|c|}{ Number of results (reviews) } \\
\hline "Thermal comfort" & 185,000 & $20,831(1201)$ & $12,830(495)$ & 466 \\
\hline “Thermal stress" & 901,000 & 75,807 (2549) & $20,113(401)$ & 254 \\
\hline "Indoor air quality" & 271,000 & $14,551(797)$ & $8046(346)$ & 290 \\
\hline "Indoor air pollution" & 94,800 & $5871(603)$ & $3086(286)$ & 64 \\
\hline "Acoustic comfort" & 9100 & $881(62)$ & $375(9)$ & 21 \\
\hline "Noise exposure" & 122,000 & $6897(500)$ & $4962(253)$ & 103 \\
\hline "Visual comfort" & 25,000 & $2646(187)$ & $1290(52)$ & 43 \\
\hline "Visual fatigue" & 18,100 & $1145(36)$ & $825(16)$ & 9 \\
\hline
\end{tabular}

Concerning the databases, it can be noted that a higher number of papers was obtained from Google Scholar, and this is also due to the impossibility to set the search option. In Science Direct and Web of Science (WOS) it was also possible to distinguish the paper type and it is was useful to easily identify the review papers.

Among these papers, the most "relevant" and the most "cited" (results sort type) were selected and reviewed by reading title, abstract and keywords. Special attention was paid on the review articles (numbers in brackets in Table 1) because they provided already organized information. Then the bibliographies of such papers were examined, in order to identify possible other interesting researches not present in the previous results. Subsequently, using the references of the consulted papers, a search was carried out aimed at identifying the original papers in which these indicators were presented for the first time.

At the same time, the websites and publications (guidelines) on these issues of the main international organizations such as the World Health Organization (WHO) and the European Agency for Safety and Health and Work (EU-OSHA) were consulted, as well as the European Directives and international standards. Overall, around 300 documents were collected which were the subject of this review article. 


\section{Health and Comfort Evaluation}

Nowadays, it has become essential to guarantee high standards of occupants' health and comfort in indoor environments (especially in the workplaces) [9,32-35]. To achieve high levels of IEQ, it is necessary to consider that the human perception of the indoor environment is affected by four basic environmental factors: thermal environment, air, acoustics, and lighting. The evaluation of each factor should be different in relation to the purpose of the investigation. Indeed, if it is necessary to consider that two different approach are generally followed for the assessment of the risk for human health and the evaluation of the human comfort.

The assessment of human health risks regards the human exposure to potentially dangerous conditions; its evaluation must include the containment measures and the risk prevention activities that are considered primary interventions. The safety of occupants represents an essential need for all environments. The aspects involved in the occupants' safety must be never overlooked. The evaluation of the risk for human health shall be generally carried out measuring some specific parameters and comparing the obtained values with the threshold values provided by the national or international standards and laws. The comparison (pass/fail) is purely quantitative.

In the ASHRAE TC 1.6 (Terminology), the IEQ is defined as "a perceived indoor experience about the building indoor environment that includes aspects of design, analysis, and operation of energy efficient, healthy, and comfortable buildings" [36]. The effects of problems related to poor IEQ levels on occupant comfort, health, well-being, and productivity were clearly demonstrated by the scientific literature [37-39]. These problems can also have consequences on the lifecycle costs and on the additional energy consumption due to the attempts to compensate for the non-adequate environmental conditions [40].

Although to guarantee a risk exempt environment is a basic need, it is not sufficient to guarantee a high level of well-being that instead can be achieved only considering the comfort perceived by the occupants, too. Figure 1 represents a map for reading the rest of the paper: each of the next sections is dedicated to an environmental factor, and for each of them, the indicators relating to comfort and risk to human health are reported and classified.

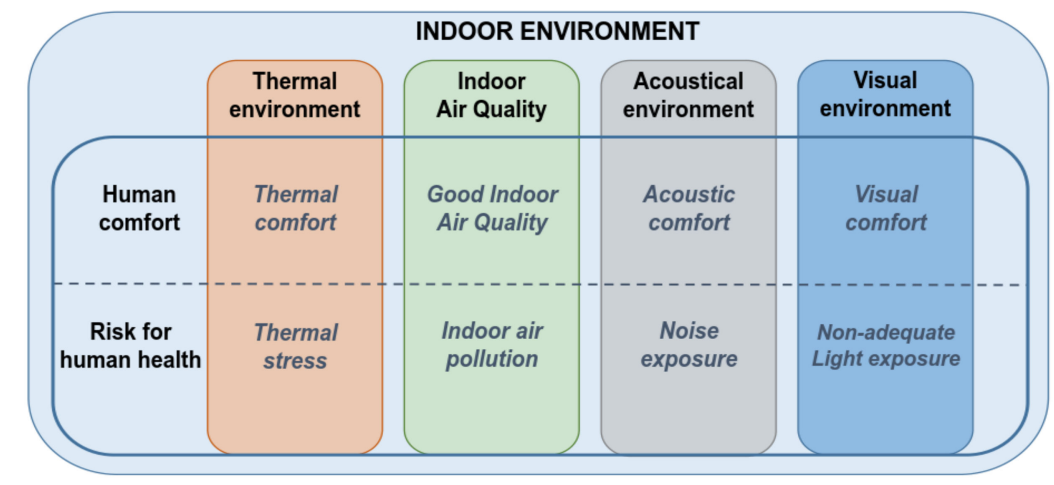

Figure 1. Main aspects related to the comfort and to the risk for human health for the four IEQ environmental factors.

With regards to comfort and health, in the ASHRAE guideline 10-2016 "Interactions Affecting the Achievement of Acceptable Indoor Environments" [1], the four main environmental factors and the interactions among environmental conditions are treated, highlighting the importance to not limit the analysis to the single environmental factor. Furthermore, "in order to provide an acceptable indoor environment, it is necessary not only that each aspect of the environment be at a satisfactory level but also that the adverse impact of interactions between these aspects is limited" [1]. The environmental factors do not necessarily have equal importance (weight), but in any case, if an environmental factor is rated as least satisfactory, it is also likely to be rated as the most relevant one. It is therefore essential 
that all aspects involved in the four environmental factors should be considered satisfactory in order not adversely affect the overall satisfaction. In the overall evaluations of the indoor environment, it is therefore important not to limit the assessments to quantitative evaluations only, but also to include qualitative considerations.

\section{Thermal Environment}

The thermal environment involves such different environmental aspects as air temperature, surrounding surface temperatures, air speed and humidity. Furthermore, the human perception of thermal comfort depends not only on physical factors, but also on metabolic activity, clothing, and personal preference. As stated by Parsons [41]: “The challenge for every person is to successfully interact with his or her local environment. The human body responds to environmental variables in a dynamic interaction that can lead to death if the response is inappropriate, or if energy levels are beyond survivable limits, and it determines the strain on the body as it uses its resources to maintain an optimum state. In the case of the thermal environment this will determine whether a person is too hot, too cold or in thermal comfort. Air temperature, radiant temperature, humidity, and air movement are the four basic environmental variables that affect human response to thermal environments. Combined with the metabolic heat generated by human activity and clothing worn by a person, they provide the six fundamental factors (sometimes called the six basic parameters as they vary in space and time but fixed representative values are often used in analysis) that define human thermal environments".

\subsection{Thermal Stress}

\subsubsection{Overview}

Thermal stress can severely affect human health, but it can also reduce attention span, increasing the risk of injury. Exposure to inadequate thermal conditions can reduce productivity and tolerance to other environmental risks. Thermal stress represents a relevant factor in many industrial situations, sports events and military scenarios [42]. In the industrial context, when people are exposed to extremely hot or cold environments, thermal discomfort is considered as one of the major causes of dissatisfaction [43]. People who work in severe hot or cold environments may lose the ability to make decisions and/or perform manual operations, and therefore the likelihood that they will behave unsafely increases. When it becomes difficult to control internal body temperature, heat stress occurs.

\subsubsection{Guidelines and Legislative Outline}

The control of thermal risks in workplaces is not included in any specific EU Directives, although such risks are covered by the general provisions of the Framework Directive (89/391/EEC) [44,45]. In any case, general recommendations on the protection of workers from thermal risks and against thermal hazards are provided in the guidelines of Workplace Safety and Health Services of the occupational national health authorities [46]. All these guidelines suggest that the temperature in the work environments should be adequate for the human body during all the work activities taking into account the physical effort of the workers. It is not sufficient consider only the effects of the temperature, but is necessary to take into consideration also the influence of humidity and ventilation in the perception of the work environment. In fact, in addition to the air temperature, other factors can help to minimize both the heat stress and the thermal discomfort. When it is not convenient to modify the temperature of the entire environment, workers must be protected against too high or too low temperatures by means of collective or individual protection devices [47]. Furthermore, Malchaire et al. [48] developed a strategy to assess the risks of heat disturbance in any work situation. This strategy is based on the three highest phases of the SOBANE strategy: "observation" to improve the thermal conditions of work; "Analysis" to assess the extent of the problem and optimize the choice of solutions; "Expert", when necessary, for an in-depth analysis of the work situation [49,50]. 


\subsubsection{Indicators}

The creation of a single indicator that allows the evaluation of the perceived thermal stress in a wide range of environmental conditions and physiological activities required numerous attempts [42]. In the Table 2, according to $[27,42,51]$, the most important thermal stress indicators proposed since 1945 are summarized and divided according to their application in hot or cold environments.

Among the thermal stress assessment indicators for hot environments, the most common is the wet bulb globe temperature (WBGT). The WBGT was introduced by the US Navy within a study on accidents related to heat during military training [52], and it was derived from the "corrected effective temperature" (CET). The WBGT comprises the weighed combination of the dry bulb (dry-bulb) (Ta), the wet bulb (wet-bulb) (Tw), and the black-globe (Tg) temperatures. Even if the WBGT has no physiological correlations, weighted coefficients were obtained empirically. The reference values of the WBGT are reported in Table 3.

Table 2. A collection of thermal stress indicators.

\begin{tabular}{|c|c|c|c|c|}
\hline Reference & Year & Index & Symbol & Application \\
\hline [53] & 1945 & Wind Chill Index & WCI & \multirow{6}{*}{ Cold Environment } \\
\hline [54] & 1984 & Required Clothing Insulation & IREQ & \\
\hline [55] & 1987 & Survival time outdoor in extreme cold & STOEC & \\
\hline [28] & 1988 & Wind-Chill Effective Temperature & WET & \\
\hline [56] & 2005 & Wind Chill equivalent Temperature & WCT & \\
\hline [57] & 2007 & Wind Chill Temperature & $t_{w c}$ & \\
\hline [58] & 1945 & Index of physiological effect & $\mathrm{E}_{\mathrm{P}}$ & \multirow{30}{*}{ Hot Environment } \\
\hline [59] & 1947 & Predicted 4-h sweat rate & P4SR & \\
\hline [60] & 1955 & Heat stress index & HIS & \\
\hline [52] & 1957 & Wet bulb globe temperature & WBGT & \\
\hline [61] & 1958 & Thermal strain index & TSI & \\
\hline [62] & 1960 & Index of physiological Strain & Is & \\
\hline [63] & 1962 & Index of Thermal Stress & ITS & \\
\hline [64] & 1966 & Heat Strain Index corrected & HIS & \\
\hline [65] & 1966 & Prediction of heart rate & HR & \\
\hline [66] & 1970 & Prescriptive zone & & \\
\hline [67] & 1971 & Wet Globe Temperature & WGT & \\
\hline [68] & 1972 & Skin wettedness & & \\
\hline [69] & 1974 & Predicted heart rate & PHR & \\
\hline [70] & 1978 & Skin wittedness & & \\
\hline [71] & 1979 & Fighter Index of Thermal Stress & FITS & \\
\hline [72] & 1981 & Effective Heat Strain Index & EHSI & \\
\hline [73] & 1982 & Predicted sweat loss & msw & \\
\hline [74] & 1984 & Munich energy balance model for individuals & MEMI & \\
\hline [74] & 1985 & Skin Temperature energy balance index & STEBIDEX & \\
\hline [75] & 1985 & Heat Budget index & HEBIDEX & \\
\hline [76] & 1996 & Cumulative Heat Strain Index & CHSI & \\
\hline [77] & 1998 & Physiological Strain Index & PSI & \\
\hline [78] & 1989 & Required sweating & SWreq & \\
\hline [79] & 2001 & Predicted Heat strain & PHS & \\
\hline [80] & 2001 & Environmental stress index & ESI & \\
\hline [81] & 2005 & Wet bulb dry temperature & WBDT & \\
\hline [82] & 2005 & Relative Humidity Dry Temperature & RHDT & \\
\hline$[83,84]$ & 2007 & Overheating Risk & OR & \\
\hline [85] & 2010 & Thermal work limit & TWL & \\
\hline [86] & 2013 & Equivalent Wet Bulb Globe Temperature & eWBGT & \\
\hline
\end{tabular}

Both ISO and ACGIH (American Conference of Governmental Industrial Hygienists) recommend considering the WBGT index as a screening tool, while the PHS (Predicted Heat Strain) approach must be used to investigate more severe working conditions in the heat. Based upon a rational approach, PHS it is the only index allowing the assessment of the work limit duration [87].

Concerning the cold environment, the most used indicator is the required clothing insulation (IREQ). The IREQ model was proposed in 1984 by Holmer [54] for the assessment of thermal stress during work in cold environments. The IREQ combines the effects of different thermo-hygrometric parameters (i.e., air temperature, mean radiant temperature, relative humidity, air velocity) with and 
metabolic activity and, in order to maintain its thermal equilibrium, it specified the required clothing insulation [88]. The IREQ is created upon rational basis and it is recommended by ISO 11079 [82,89].

Table 3. Example of WBGT reference values.

\begin{tabular}{|c|c|c|c|}
\hline \multirow[b]{2}{*}{ Metabolic Rate Class } & \multirow{2}{*}{$\begin{array}{c}\text { Metabolic Rate } \\
\text { W }\end{array}$} & \multicolumn{2}{|c|}{ Reference Value of WBGT } \\
\hline & & $\begin{array}{c}\text { PERSONS Acclimatized } \\
\text { to Heat } \\
{ }^{\circ} \mathrm{C}\end{array}$ & $\begin{array}{c}\text { Persons Unacclimatized } \\
\text { to Heat } \\
{ }^{\circ} \mathrm{C}\end{array}$ \\
\hline 0 Resting metabolic rate & 115 & 33 & 32 \\
\hline 1 Low metabolic rate & 180 & 30 & 29 \\
\hline 2 Moderate metabolic rate & 300 & 28 & 26 \\
\hline 3 High metabolic rate & 415 & 26 & 23 \\
\hline 4 Very high metabolic rate & 520 & 25 & 20 \\
\hline
\end{tabular}

\subsection{Thermal Comfort}

\subsubsection{Overview}

The American Society of Heating, Refrigerating and Air-Conditioning Engineers (ASHRAE) defined thermal comfort as "the condition of the mind in which satisfaction is expressed with the thermal environment" [90]. In addition to environmental conditions, the perception of thermal comfort can be influenced by personal differences in mood, culture and other social factors. In the ASHRAE definition, thermal comfort is not only a state condition, but rather a state of mind (a cognitive process that involves many inputs influenced by physical, physiological and other factors). "Satisfaction with the thermal environment is a complex subjective response to several interacting and less tangible variables" [29]. An absolute thermal comfort condition does not exist; the sensation of thermal comfort occurs when the body temperatures fall in rather narrow intervals, the moisture on the skin is low, and the physiological effort is minimal [29].

\subsubsection{Indicators}

Nowadays, for the evaluation of the thermal comfort, two main approaches are proposed: the rational or heat balance approach, and the adaptive approach. The first uses data from climate chamber studies to support its theory, the second uses data from field studies of people in buildings.

The heat balance approach is based on the results of the experiments carried out by Fanger in 1970 [91]. Using a steady-state heat transfer model, Fanger studied the response of a sample of 126 Danish student who underwent specific tests in a climate chamber [92]. Then, in order to determine range of comfort temperature in which the occupant feel comfortable, he combines theories on heat balance with the physiology of the thermoregulation. In order to maintain a balance between the heat produced by metabolism and the heat lost from the body, the human body is engaged in physiological processes (e.g., sweating, shivering, regulating blood flow to the skin). Consequently, the condition in which this thermal equilibrium is maintained can be considered the first condition to obtain a neutral thermal sensation [29]. Then, the tests were repeated until they involved a sample of 1296 participants, and a comfort equation was obtained that could predict when the occupants feel thermally neutral.

With the Fanger comfort equation it is possible to calculate all combinations of the environmental variables (air temperature, air humidity, mean radiant temperature and relative air velocity) which will create optimal thermal comfort for any activity level and any clothing insulation [92]. The comfort equation related thermal conditions to the seven-point ASHRAE thermal sensation scale and became known as the predicted mean vote (PMV) indicator. Furthermore, to the PMV, the predicted percentage of dissatisfied (PPD) was added in order to obtain a direct information of the percentage number of people who may experience discomfort. Using the Predicted Mean Vote and the PDD indicators it is possible to assess the thermal sensation perceived by occupants of indoor environments. It is important to note that the PMV should be calculated taking into account the range of application and 
the limitations, as it is very often improperly used without taking into account all the input variables, or calculated outside its range of validity $[93,94]$.

The adaptive thermal comfort approach is based on the consideration that occupants are passive subjects, but they constantly interacting with the environment and adapting to it [95]. Using this approach, thermal perception is determined in relation to the indoor operating temperature and the outdoor air temperature. The adaptive thermal comfort approach takes into account that there are different factors that affects the thermal perception. These factors can include such different aspects as: demographics (gender, age, economic status), context (building design, building function, season, climate, social conditioning), and cognition (attitude, preference, and expectations) [96]. The adaptation can be divided into three different categories: behavioral, psychological, and physiological.

Behavioral adaptation is the most important factor and it offers the opportunity to adjust the body's heat balance to maintain thermal comfort by changing the clothing levels, opening or closing the windows, and switching on/off the fans. Psychological adaptation describes how habits and expectations can change perceptions of the thermal environment and, more specifically, it refers to the effects of the cognitive, social, and cultural variables. Physiological adaptation or acclimatization is the less relevant of the three aspects in the moderate range of more common indoor environmental conditions [97].

Although the Fanger indicators (PMV and PPD) are the most widely used [15-17], in the literature, other indicators for the evaluation of thermal comfort were proposed, among which some of these were designed to better evaluate the thermal sensation in particular climatic conditions. A collection of the indicators found in the literature with the reference of the scientific publications in which they were proposed, is reported in Table 4 . These indicators were classified in relation to the number of parameters necessary for their determination. In particular, they were classified in: "single parameters based" (if directly obtained from one parameter), "double parameters based" (if obtained from the combination of two parameters), and in "multiple parameters based" (if obtained from the combination of three or more parameters).

\subsubsection{Current Research Trends}

Climate change, the urgency to decarbonize the built environment, and the reduction of energy consumption are still the topics of greatest interest. The increased policy attention on these topics has increased research and development investment. The demand for increasingly high-performance buildings has led to the research of new strategies to mitigate energy consumption and environmental impact. The new challenge is to minimize energy consumption by guaranteeing high housing standards. For this reason, the thermal comfort indicators suitable for evaluating air-conditioned environments and occupant interaction with plant systems are still studied.

The use of adaptive thermal comfort models can be particularly well combined with climate-based software for the dynamic simulation of the buildings behavior that allow to study the variation of internal conditions in relation to the external temperature changes. The comfort simulation methods based on easily accessible numerical simulation tools of the built environment are becoming more popular. A possible critical aspect of this method concerns the risk of moving too far away from the actual behavior of the users, which is very often difficult to predict. Practitioners' confidence in comfort models (design phase) and in engineering calculations, as well as conformity assessments for existing buildings, is widespread and perfectly reasonable. However, subjective surveys of thermal comfort are a superior contribution to knowledge, with more lasting value for the research community than simulated comfort assessments coming from a comfort model [98]. 
Table 4. A collection of thermal comfort indicators.

\begin{tabular}{|c|c|c|c|c|c|}
\hline Reference & Index & Symbol & Parameters & Year & Category \\
\hline [99] & Wet bulb temperature & $\mathrm{T}_{\mathrm{W}}$ & & 1905 & \multirow{4}{*}{$\begin{array}{l}\text { Single } \\
\text { parameter } \\
\text { based }\end{array}$} \\
\hline [100] & Katathermometer & & & 1914 & \\
\hline [101] & $\begin{array}{l}\text { Globe-Thermometer } \\
\text { Temperature }\end{array}$ & $\mathrm{GtT}$ & & 1930 & \\
\hline [102] & Effective Radiant Field & ERF & & 1967 & \\
\hline [103] & Humiture or Heat Index & $\mathrm{HI}$ & Air temperature, humidity. & 1937 & \multirow{16}{*}{$\begin{array}{l}\text { Double } \\
\text { parameters } \\
\text { based }\end{array}$} \\
\hline [104] & Craig Index & I & $\begin{array}{l}\text { Heart rate, predicted } \\
\text { body temperature }\end{array}$ & 1950 & \\
\hline [105] & Oxford index & WD & $\begin{array}{l}\text { Wet-bulb temperature, } \\
\text { Dry-bulb temperature }\end{array}$ & 1957 & \\
\hline [106] & Discomfort index & DI & $\begin{array}{l}\text { Wet-bulb temperature, } \\
\text { Dry-bulb temperature }\end{array}$ & 1957 & \\
\hline [107] & $\begin{array}{l}\text { Cumulative Discomfort } \\
\text { Index }(* *)\end{array}$ & CumDI & $\begin{array}{l}\text { Wet-bulb temperature, } \\
\text { Dry-bulb temperature }\end{array}$ & 1961 & \\
\hline [108] & Humiture revisited & & Air temperature, humidity. & 1960 & \\
\hline [109] & Relative Strain Index & RSI & $\begin{array}{l}\text { Air temperature, water } \\
\text { vapor pressure. }\end{array}$ & 1963 & \\
\hline [110] & $\begin{array}{l}\text { Temperature-Humidity } \\
\text { Index }\end{array}$ & THI & $\begin{array}{c}\text { Air temperature, } \\
\text { Relative Humidity }\end{array}$ & 1977 & \\
\hline [111] & Humidex & $\mathrm{H}$ & $\begin{array}{l}\text { Air Temperature, water } \\
\text { vapor pressure }\end{array}$ & 1979 & \\
\hline [112] & Humisery & & $\begin{array}{l}\text { Air temperature, } \\
\text { Relative Humidity }\end{array}$ & 1982 & \\
\hline [113] & Summer simmer Index & SSI & $\begin{array}{l}\text { Air temperature, } \\
\text { Relative Humidity }\end{array}$ & 1987 & \\
\hline [114] & Modified discomfort index & MDI & $\begin{array}{l}\text { Wet-bulb temperature, } \\
\text { Dry-bulb temperature }\end{array}$ & 1998 & \\
\hline [115] & $\begin{array}{l}\text { New Summer Simmer } \\
\text { Index }\end{array}$ & newSSI & $\begin{array}{l}\text { Air temperature, } \\
\text { Relative Humidity }\end{array}$ & 2000 & \\
\hline [116] & Degree-hour criterion $(* *)$ & & $\begin{array}{l}\text { Air temperature, mean } \\
\text { radiant temperature }\end{array}$ & 2007 & \\
\hline [117] & EsConTer Index & & $\begin{array}{l}\text { Wet-bulb temperature, } \\
\text { Dry-bulb temperature }\end{array}$ & 2009 & \\
\hline [118] & Exceedance $_{M}(* *)$ & & $\begin{array}{l}\text { Air temperature, mean } \\
\text { radiant temperature }\end{array}$ & 2010 & \\
\hline [119] & Effective temperature & ET & $\begin{array}{l}\text { Dry-bulb temperature, air } \\
\text { temperature, humidity, } \\
\text { radiant conditions, } \\
\text { air movements. }\end{array}$ & 1923 & \multirow{8}{*}{$\begin{array}{c}\text { Multi-parameters } \\
\text { based }\end{array}$} \\
\hline [120] & Equivalent temperature & $\mathrm{T}_{\mathrm{eq}}$ & $\begin{array}{l}\text { Dry-bulb temperature, air } \\
\text { temperature, radiant } \\
\text { temperature, humidity. }\end{array}$ & 1929 & \\
\hline [121] & $\begin{array}{l}\text { Corrected effective } \\
\text { temperature }\end{array}$ & CET & $\begin{array}{l}\text { Dry-bulb temperature, air } \\
\text { temperature, humidity, } \\
\text { radiant conditions, } \\
\text { air movements. }\end{array}$ & 1932 & \\
\hline [122] & $\begin{array}{l}\text { Standard Operative } \\
\text { Temperature }\end{array}$ & SOpT & $\begin{array}{l}\text { Air temperature, air velocity, } \\
\text { solar radiation, body } \\
\text { temperature. }\end{array}$ & 1937 & \\
\hline [123] & Operative temperature & $\mathrm{T}_{\mathrm{o}}$ & $\begin{array}{l}\text { Air temperature, mean radiant } \\
\text { temperature, air velocity }\end{array}$ & 1937 & \\
\hline [124] & Thermal acceptance ratio & TAR & $\begin{array}{l}\text { Vapor pressure, metabolic } \\
\text { heat, skin temperature, } \\
\text { evaporation, convection and } \\
\text { radiation constants. }\end{array}$ & 1945 & \\
\hline [125] & $\begin{array}{l}\text { Corrected Effective } \\
\text { Temperature }\end{array}$ & CET & $\begin{array}{l}\text { Dry-bulb temperature, } \\
\text { humidity, radiant conditions, } \\
\text { air movements. }\end{array}$ & 1946 & \\
\hline [126] & Resultant temperature & RT & $\begin{array}{l}\text { Dry-bulb temperature, air } \\
\text { temperature, humidity, } \\
\text { radiant conditions, } \\
\text { air movements. }\end{array}$ & 1948 & \\
\hline
\end{tabular}


Table 4. Cont.

\begin{tabular}{|c|c|c|c|c|c|}
\hline Reference & Index & Symbol & Parameters & Year & Category \\
\hline [52] & $\begin{array}{l}\text { Effective Temperature } \\
\text { including radiantion }\end{array}$ & ETR & $\begin{array}{l}\text { Dry-bulb temperature, air } \\
\text { temperature, humidity, globe } \\
\text { thermometer temperature, } \\
\text { air movements. }\end{array}$ & 1957 & \multirow{17}{*}{$\begin{array}{l}\text { Multi-parameters } \\
\text { based }\end{array}$} \\
\hline [127] & Equatorial comfort index & ECI & $\begin{array}{l}\text { Wet-bulb temperature, Dry-bulb } \\
\text { temperature, air velocity, } \\
\text { geographic coordinates }\end{array}$ & 1959 & \\
\hline [128] & $\begin{array}{l}\text { Cumulative Effective } \\
\text { Temperature }(* *)\end{array}$ & CumET & $\begin{array}{l}\text { Dry-bulb temperature, air } \\
\text { temperature, humidity, radiant } \\
\text { conditions, air movements. }\end{array}$ & 1962 & \\
\hline [91] & Predicted mean vote & PMV & $\begin{array}{l}\text { Air temperature, relative } \\
\text { humidity, mean radiant } \\
\text { temperature and relative air } \\
\text { velocity, metabolic } \\
\text { activity, clothing. }\end{array}$ & 1970 & \\
\hline [129] & New effective temperature & $\mathrm{ET}^{*}$ & $\begin{array}{l}\text { Dry-bulb temperature, air } \\
\text { temperature, humidity, radiant } \\
\text { conditions, air movements. }\end{array}$ & 1971 & \\
\hline [130] & $\begin{array}{l}\text { Humid operative } \\
\text { temperature }\end{array}$ & $\mathrm{T}_{\mathrm{OH}}$ & $\begin{array}{l}\text { Air temperature, mean radiant } \\
\text { temperature, dew point } \\
\text { temperature, skin temperature, } \\
\text { air movements, clothing. }\end{array}$ & 1971 & \\
\hline [131] & Apparent Temperature & AT & $\begin{array}{l}\text { Air temperature, relative } \\
\text { humidity, air velocity. }\end{array}$ & 1971 & \\
\hline [132] & $\begin{array}{l}\text { Standard effective } \\
\text { temperature }\end{array}$ & SET & $\begin{array}{l}\text { Dry-bulb temperature, air } \\
\text { temperature, humidity, radiant } \\
\text { conditions, air movements. }\end{array}$ & 1973 & \\
\hline [133] & $\begin{array}{l}\text { Apparent Temperature } \\
\text { (revised) }\end{array}$ & AT & $\begin{array}{l}\text { Air temperature, relative } \\
\text { humidity, air velocity. }\end{array}$ & 1979 & \\
\hline [134] & $\begin{array}{l}\text { Equivalent Uniform } \\
\text { Temperature }\end{array}$ & EUT & $\begin{array}{l}\text { Air temperature, relative } \\
\text { humidity, mean radiant } \\
\text { temperature and relative air } \\
\text { velocity, metabolic } \\
\text { activity, clothing. }\end{array}$ & 1980 & \\
\hline [135] & $\begin{array}{l}\text { Predicted mean vote } \\
\text { modified }\end{array}$ & PMV * & $\begin{array}{l}\text { Air temperature, relative } \\
\text { humidity, mean radiant } \\
\text { temperature and relative air } \\
\text { velocity, metabolic } \\
\text { activity, clothing. }\end{array}$ & 1986 & \\
\hline [136] & Tropical Summer Index & TSI & $\begin{array}{l}\text { Wet-bulb temperature, globe } \\
\text { temperature, Relative Humidity, }\end{array}$ & 1987 & \\
\hline [137] & CIBSE Guide J-criterion & & $\begin{array}{l}\text { Dry-bulb temperature, mean } \\
\text { radiant temperature, air velocity. }\end{array}$ & 2002 & \\
\hline [138] & $\begin{array}{l}\text { PPD weighted criterion } \\
\qquad(* *)\end{array}$ & & $\begin{array}{l}\text { Air temperature, relative } \\
\text { humidity, mean radiant } \\
\text { temperature and relative air } \\
\text { velocity, metabolic } \\
\text { activity, clothing. }\end{array}$ & 2005 & \\
\hline [138] & Average PPD $(* *)$ & & $\begin{array}{l}\text { Air temperature, relative } \\
\text { humidity, mean radiant } \\
\text { temperature and relative air } \\
\text { velocity, metabolic } \\
\text { activity, clothing. }\end{array}$ & 2005 & \\
\hline [138] & Cumulative PPD $\left({ }^{* *}\right)$ & & $\begin{array}{l}\text { Air temperature, relative } \\
\text { humidity, mean radiant } \\
\text { temperature and relative air } \\
\text { velocity, metabolic } \\
\text { activity, clothing. }\end{array}$ & 2005 & \\
\hline$[116]$ & CIBSE Guide A-criterion & & $\begin{array}{l}\text { Dry-bulb temperature, mean } \\
\text { radiant temperature, air velocity. }\end{array}$ & 2006 & \\
\hline
\end{tabular}

Note $\left.{ }^{* *}\right)$ : indicators that require monitoring in pre-established time intervals and the determination of the percentage of time in which a certain parameter falls outside the relative reference value. 


\section{Indoor Air Quality}

Clean air is considered a basic requirement of human health, well-being, comfort and productivity [139]. Indoor air quality is affected by different factors as the interactions between building materials, building services, location, climate, contaminant sources, and occupancy [140-143]. Indoor air quality can be approached from three points of view: the human, the air of the indoor space, and the sources contributing to indoor air pollution [136].

From the human point of view, indoor air quality is the physical effect of people's exposures to substances in the indoor air. From the indoor air point of view, indoor air quality is often expressed with the ventilation rate or with the concentrations for specific compounds. From the sources point of view, air pollution levels may be higher near specific air pollution sources such as roads; the protection of people from air pollution may require specific measures to maintain the pollution levels below the threshold values indicated in the national and international guidelines [139].

\subsection{Indoor Air Pollution}

\subsubsection{Overview}

Considering that especially in urban areas, people spend long periods of time in indoor environments, the international scientific community deals with air pollution in living environments because indoor pollution can cause side effects ranging from discomfort to serious health consequences. In this regard, illness such as sick building syndrome (SBS) $[144,145]$ and building related illness (BRI) are referred to [145]. It is important to note that a study conducted by the United States Environmental Protection Agency (EPA) in 1998 has estimated that indoor concentrations and indoor exposures are generally 1-5 times, and 10-50 times higher than outdoor ones, respectively [146]. In 2000, the World Health Organization (WHO), with the document "The Right to Healthy Indoor Air", recognized a healthy indoor air as a fundamental human right [147].

\subsubsection{Guidelines and Legislative Outline}

The WHO, with "the health for all in the 21st century", provided a policy framework for the European region [148]. The target was that, by the year 2015, people in the EU region had to live in a safer physical environment, with contaminants exposure lower than internationally agreed thresholds. This target has consequently resulted in the introduction of legislative measures for the regulation of the surveillance and control of the air quality in both indoor and outdoor environments.

The healthiness of the indoor air is influenced by such different factors as undesirable substances emitted by construction, furniture materials, and human being, as well as ventilation and heating systems if not adequately cleaned. Concerning the indoor air quality, it is important to consider individual exposure to pollutants that can be defined as the air pollutants concentration over time. This depends upon several aspects: the emission rate of a pollutant $\left(\mu \mathrm{g} / \mathrm{s}\right.$ or $\mu \mathrm{g} / \mathrm{s}$ per $\mathrm{m}^{2}$ surface area of source); the ventilation rate of the space in which the pollutants are produced $\left(\mathrm{m}^{3} / \mathrm{h} \mathrm{or} \mathrm{L/s);}\right.$ the pollutants concentration in the ventilation air $\left(\mathrm{ppm}\right.$ or $\left.\mu \mathrm{g} / \mathrm{m}^{3}\right)$.

In Italy, a clear legislative framework for the control and the maintenance of the air quality in the indoor environment does not exist. In the national law 81/2008 [47], the only limit values provided are referred to the concentrations of $\mathrm{CO}_{2}$, radon, and bacteria allowed in the indoor environment during the daily activities. For example, the maximum permissible level of $\mathrm{CO} 2$ is equal to $5000 \mathrm{ppm}$ in a time interval of eight working hours.

\subsubsection{Air Pollutants}

At the international level, the exposure limit values of a wide range of pollutants were defined by the EU and the WHO [44]. Since 1958, when the first report was published, the WHO has been working on the potential adverse effects on health of air quality [149-151]. In the first edition of the WHO air quality guidelines (AQGs) [152], 28 air pollutants (organic and inorganic) were classified, and different 
approaches to deal with carcinogenic (i.e., unit risk factors) and non-carcinogenic-health (i.e., LOAEL and protection factors) aspects were used. Furthermore, $\mathrm{SO}_{2}$ and particulate matter (PM) were considered jointly. The second edition of the WHO AQGs was published in 2000 [153], following the evidence of health effects occurring at lower levels of exposure, and it was considered as a starting point for the EU Air Quality Directive and the definition of legally binding limit values [154]. In this AQGs 32 air pollutants are concerned (see Table 5), moreover the assessments for three organic air pollutants (butadiene, polychlorinated biphenyls and polychlorinated dibenzodioxins and dibenzofurans) and a specific section for indoor air pollutants (radon, environmental tobacco smoke, and man-made vitreous fibers) are included.

The latest WHO AQGs "WHO Air Quality Guidelines, Global Update 2005" [155] concerned the policy development and risk reduction application of AQGs, as well as a comprehensive risk assessment for the four classical air pollutants: $\mathrm{PM}, \mathrm{O}_{3}, \mathrm{NO}_{2}$, and $\mathrm{SO}_{2}$. In addition to numerical guidelines, it also proposed interim targets above the guideline value to promote steady progress in different world regions [155]. Moreover, the WHO has published a series of indoor AQGs on dampness and mould, selected pollutants, and household fuel combustion [156-158]. In Table 6 are shown the limit values of the air pollutants with the latest version of the relative WHO Air quality guidelines (WHO AQGs).

Table 5. Summary of the most important air pollutants.

\begin{tabular}{|c|c|c|}
\hline Organic Pollutants & Inorganic Pollutants & Classical Pollutants \\
\hline $\begin{array}{l}\text { Acrylonitrile; Butadiene; Benzene; Carbon disulfide; } \\
\text { Carbon monoxide; 1.2 Dichloromethane; }\end{array}$ & \multirow{3}{*}{$\begin{array}{c}\text { Arsenic; Asbestos; Cadmium; } \\
\text { Chromium; Fluoride; Hydrogen } \\
\text { sulfide; Lead; Manganese; } \\
\text { Mercury; Nickel; } \\
\text { Platinum; Vanadium }\end{array}$} & $\begin{array}{l}\text { Particulate matter; Ozone and } \\
\text { other photochemical oxidants; } \\
\text { Nitrogen dioxide; Sulfur dioxide }\end{array}$ \\
\hline $\begin{array}{l}\text { Dichloromethane; Formaldehyde; Polycyclic aromatic } \\
\text { hydrocarbons; Polychlorinated biphenyls; Styrene; }\end{array}$ & & Indoor Air Pollutants \\
\hline $\begin{array}{c}\text { Tetrachloroethylene; Toluene; Trichloroethylene; Vinyl } \\
\text { chloride; Polychlorinated dibenzodioxins } \\
\text { and dibenzofurans. }\end{array}$ & & $\begin{array}{l}\text { Man-made vitreous fibers; } \\
\text { Environmental tobacco } \\
\text { smoke; Radon. }\end{array}$ \\
\hline
\end{tabular}


Table 6. Example of limit values for the air pollutants.

\begin{tabular}{|c|c|c|c|c|}
\hline Pollutant & Symbol & Limit Values & Reference Period & $\begin{array}{l}\text { Year of Latest } \\
\text { WHO AQGs }\end{array}$ \\
\hline \multicolumn{5}{|c|}{ Organic Pollutants } \\
\hline Carbon disulphide & $\mathrm{CS}_{2}$ & $\begin{array}{l}100 \mu \mathrm{g} / \mathrm{m}^{3} \\
20 \mu \mathrm{g} / \mathrm{m}^{3}\end{array}$ & $\begin{array}{c}24 \mathrm{~h} \\
30 \mathrm{~min}\end{array}$ & 1987 \\
\hline 1,2-Dichloroethane & EDC & $0.7 \mathrm{mg} / \mathrm{m}^{3}$ & $24 \mathrm{~h}$ & 2000 \\
\hline Dichloromethane & DCM & $3.0 \mathrm{mg} / \mathrm{m}^{3}$ & $24 \mathrm{~h}$ & 2000 \\
\hline Formaldehyde & & $100 \mu \mathrm{g} / \mathrm{m}^{3}$ & $30 \mathrm{~min}$ & 2010 \\
\hline Styrene & & $\begin{array}{c}0.26 \mathrm{mg} / \mathrm{m}^{3} \\
70 \mu \mathrm{g} / \mathrm{m}^{3}\end{array}$ & $\begin{array}{l}\text { Weekly } \\
30 \text { min }\end{array}$ & 2000 \\
\hline Tetrachloroethylene & PERC & $\begin{array}{c}0.25 \mathrm{mg} / \mathrm{m}^{3} \\
8 \mathrm{mg} / \mathrm{m}^{3}\end{array}$ & $\begin{array}{l}\text { Annual } \\
30 \text { min }\end{array}$ & 2010 \\
\hline Toluene & & $\begin{array}{c}0.26 \mathrm{mg} / \mathrm{m}^{3} \\
1 \mathrm{mg} / \mathrm{m}^{3}\end{array}$ & $\begin{array}{l}\text { Weekly } \\
30 \mathrm{~min}\end{array}$ & 2000 \\
\hline \multicolumn{5}{|c|}{ Inorganic Pollutants } \\
\hline Cadmium & $\mathrm{Cd}$ & $100 \mathrm{mg} / \mathrm{m}^{3}$ & $30 \mathrm{~min}$ & 2000 \\
\hline Hydrogen sulphide & $\mathrm{H}_{2} \mathrm{~S}$ & $\begin{array}{c}150 \mu \mathrm{g} / \mathrm{m}^{3} \\
7 \mu \mathrm{g} / \mathrm{m}^{3}\end{array}$ & $\begin{array}{c}24 \mathrm{~h} \\
30 \mathrm{~min}\end{array}$ & 2000 \\
\hline Lead & $\mathrm{Pb}$ & $0.5 \mu \mathrm{g} / \mathrm{m}^{3}$ & Annual & 2000 \\
\hline Manganese & $\mathrm{Mn}$ & $0.15 \mu \mathrm{g} / \mathrm{m}^{3}$ & Annual & 2000 \\
\hline Mercury & $\mathrm{Hg}$ & $1 \mu \mathrm{g} / \mathrm{m}^{3}$ & Annual & 2000 \\
\hline $\begin{array}{l}\text { Vanadium } \\
\text { pentoxide }\end{array}$ & & $1 \mu \mathrm{g} / \mathrm{m}^{3}$ & $24 \mathrm{~h}$ & 1987 \\
\hline \multicolumn{5}{|c|}{ Classical Pollutants } \\
\hline \multirow{2}{*}{ Particulate matter } & PM2.5 & $\begin{array}{l}10 \mu \mathrm{g} / \mathrm{m}^{3} \\
25 \mu \mathrm{g} / \mathrm{m}^{3}\end{array}$ & $\begin{array}{c}\text { Annual } \\
24 \mathrm{~h}\end{array}$ & \multirow{2}{*}{2006} \\
\hline & PM10 & $\begin{array}{l}20 \mu \mathrm{g} / \mathrm{m}^{3} \\
50 \mu \mathrm{g} / \mathrm{m}^{3}\end{array}$ & $\begin{array}{l}\text { Annual } \\
24 \mathrm{~h}\end{array}$ & \\
\hline Ozone & $\mathrm{O}_{3}$ & $100 \mu \mathrm{g} / \mathrm{m}^{3}$ & $8 \mathrm{~h}$ & 2006 \\
\hline Nitrogen dioxide & $\mathrm{NO}_{2}$ & $\begin{array}{c}40 \mu \mathrm{g} / \mathrm{m}^{3} \\
200 \mu \mathrm{g} / \mathrm{m}^{3}\end{array}$ & $\begin{array}{c}\text { Annual } \\
1 \mathrm{~h}\end{array}$ & 2010 \\
\hline Sulphur dioxide & $\mathrm{SO}_{2}$ & $\begin{array}{c}20 \mu \mathrm{g} / \mathrm{m}^{3} \\
500 \mu \mathrm{g} / \mathrm{m}^{3}\end{array}$ & $\begin{array}{c}24 \mathrm{~h} \\
10 \mathrm{~min}\end{array}$ & 2006 \\
\hline
\end{tabular}

\subsection{Good Indoor Air Quality}

\subsubsection{Overview}

Indoor air quality (IAQ), in terms of comfort, is very important because it affects building occupants and their ability to conduct activities, in addition to creating positive or negative impressions on customers, clients, and other visitors.

When IAQ is not adequate, building owners and managers must devote considerable resources to resolve occupant complaints or deal with long periods of building closure, major repair costs, and expensive legal actions. On the contrary, when IAQ is good, building are more desirable places to work, to learn, to conduct business, and to rent $[159,160]$.

High levels of IAQ are achieved by providing air in which there are low contaminant concentrations and no conditions that can be associated with occupant health or comfort complaints. The current knowledge on the health and comfort impacts of specific contaminants and contaminant mixture in nonindustrial environments, does not allow for the development of a single IAQ metric able to provide a summary measure of IAQ in buildings [159]. Considering the difficulties associated with the air quality assessment in confined environments, to date has not possible to formulate a universally accepted air quality definition. At present, for buildings, the definition of the ASHRAE 
considers acceptable the indoor air quality when "it does not contain known contaminants in harmful concentrations, as established by the competent authorities, and for which a substantial majority of people exposed (80\% or more) does not express dissatisfaction" [161].

\subsubsection{Indicators}

Regarding the air quality assessment indicators, it is certainly important to mention the 1987 Fanger study [162]. Fanger, similarly to what was previously done for the evaluation of thermal comfort, introduced a subjective indicator called DECIPOL. The DECIPOL is defined as "pollution perceived in the presence of a normal subject (1 olf) in an environment with ventilation equal to $10 \mathrm{~L} / \mathrm{s}$ of clean air". In the DECIPOL definition, 1 olf represents the main quantity and it is defined as the "amount of bio-effluents emitted from a standard source consisting of a subject that performs sedentary activities in conditions of thermal well-being with a hygienic standard of 0.7 baths/d" [162].

Later, different IAQ indicators were proposed for the evaluation of IAQ in buildings [163-177]. Two different approaches are commonly used to construct IAQ indicators: subjective surveys and field measurements [178].

The IAQ indicators based on subjective surveys include the administration of questionnaires on the perception of IAQ and indoor comfort, (e.g., the ABCD tool proposed in the Netherlands [179]) or the compilation of checklists describing building facilities (e.g., Indoor airPLUS proposed by the USA Environmental Protection Agency [180]).

The IAQ indicators based on field measurements, such as the BILGA index [163,164] and the IAQ Certification [165], are more common, and generally they can be calculated using equations, e.g., the indoor environmental index (IEI) proposed in the USA [176-178]. According to [181], the IAQ indicators can be classified according to used approaches in: "one indicator per single pollutant"; "simple aggregation"; "aggregation according to the sources of pollutants and/or types of pollutants"; "aggregation accounting for the IAQ of the building stock"; "aggregation by simple addition of health impacts". Among the more recent studies, it is possible to find comfort indicators built on the basis of the PMV proposed by Fanger for the thermal comfort. In particular, Zhu and Li [182] tried to connect the objective environment parameters with the subjective comfort perception introducing the indoor air quality indicator $\mathrm{PMV}_{\mathrm{IAQ}}$. Such an indicator is defined as the maximum value of the PMV indicators related to three different pollutant concentrations: $\mathrm{CO} 2\left(\mathrm{PMV}_{\mathrm{CO} 2}\right), \mathrm{PM}_{10}\left(\mathrm{PMV}_{\mathrm{PM} 10}\right)$, and the formaldehyde $\left(\mathrm{PMV}_{\mathrm{HCHO}}\right)$.

The main indoor air quality indicators proposed in literature are collected in Table 7. 
Table 7. A collection of indoor air quality indicators.

\begin{tabular}{|c|c|c|c|c|}
\hline Reference & Symbol & Pollutants & Category & Year \\
\hline [169] & & $\begin{array}{c}\text { Any } \\
\mathrm{CO}_{2} \text {, TVOC }\end{array}$ & $\begin{array}{l}\text { One index per single } \\
\text { pollutant * }\end{array}$ & 2016 \\
\hline$[163,164]$ & BILGA & Any & & 1996 \\
\hline$[164,170]$ & CLIM2000 & $\mathrm{CO}, \mathrm{CO}_{2}, \mathrm{NO}_{2}$, formaldehyde & & 1996 \\
\hline$[164,170]$ & LHVP & $\mathrm{CO}, \mathrm{CO}_{2}$, bacteria & Simple aggregation & 1998 \\
\hline [166-168] & IEI & $\mathrm{CO}, \mathrm{CO}_{2}$, formaldehyde, TVOC, PM10 & & 2002 \\
\hline [165] & IAQC & $\mathrm{CO}, \mathrm{CO}_{2}$, formaldehyde, TVOC, PM10 & & 2003 \\
\hline [172] & QUAD & $\begin{array}{c}\text { Group } \mathrm{A}: \mathrm{CO}_{2} \\
\text { Group B: } \mathrm{NO}_{2}, \mathrm{SO}_{2}, \mathrm{O}_{3} \\
\text { Group C: } \mathrm{CO}, \text { formaldehyde, } \\
\text { acetaldehyde, ethylbenzene, styrene, } \\
\text { toluene, o-xylene, acetone } \\
\text { Group D: PM2.5, PM10 }\end{array}$ & $\begin{array}{l}\text { Aggregation according the } \\
\text { sources of pollutants } \\
\text { and/or type of pollutants }\end{array}$ & 2012 \\
\hline [173] & IAPI & $\begin{array}{c}\mathrm{CO}, \mathrm{CO}_{2} \text {, formaldehyde, TVOC, PM2.5, } \\
\text { PM10, fungi, bacteria }\end{array}$ & $\begin{array}{l}\text { Aggregation accounting } \\
\text { for the IAQ in the } \\
\text { building stock }\end{array}$ & 2003 \\
\hline [174] & DALY & Any & $\begin{array}{l}\text { Aggregation by simple } \\
\text { addition of health impacts }\end{array}$ & 2011 \\
\hline [182] & $\mathrm{PMV}_{\mathrm{IAQ}}$ & $\mathrm{CO}_{2} ; \mathrm{PM} 10 ; \mathrm{HCHO}$ & $\begin{array}{c}\text { One index per single } \\
\text { pollutant; and an overall } \\
\text { index }\end{array}$ & 2017 \\
\hline
\end{tabular}

* One index per single indicators are commonly obtained with the ratio between the concentration of the pollutants and the relative exposure limit value.

\subsubsection{Current Research Trends}

Despite the existing air quality indicators, the lack of metrics which quantitatively describe the IAQ can be regarded as one of the most relevant complications for the achievement of the integration of energy and IAQ strategies in indoor environment design. Such an indicator could allow the analysis and comparisons of different plans for achieving high IAQ levels, high energy performance, and low greenhouse gas emissions [183]. Recently, the International Energy Agency (IEA) in agreement with the Energy in Buildings and Communities (EBC) defined a project (IAE EBC annex 68) to provide a guideline for the design and control strategy of high energy efficiency residential buildings. One of the first steps of this project is to define an indicator that will have to include the additional energy consumption necessary to improve IAQ (compared to standard practices), e.g., an increased consumption induced by higher air change rates $[181,183]$.

\section{Acoustical Environment}

People are continuously exposed to noise, even when they sleep. Consequently, for workers, whether alone in a private office or among a large number of colleagues in an industrial setting, a complete absence of noise never occurs. A good acoustical environment should not involve any physical, physiological or psychological effects on the human body that could negatively affect health. Furthermore, the acoustical environment should allow a person to be in the most suitable state of mind for a specific activity [184]. On the contrary, exposure to noise can affect quality of life and, in the worst case, can lead to health problems. A workplace with good acoustics allows for confidential conversations between collaborators without affecting those engaged in individual work. The internal environment must protect from excessive noise pollution from internal and external sources and encourage the performance of the planned activities, specifically in all those environments where verbal communication and correct listening take priority (i.e., schools, conference rooms, etc.). 


\subsection{Noise Exposure}

\subsubsection{Overview}

The effects that caused by excessive noise exposure are now well known and they can even lead to hearing loss (e.g., hypoacusis). Noise exposure can also cause effects on other organs such as the cardiovascular, the endocrine, and the central nervous systems, and it involves different effects such as fatigue, interference with sleep and rest, and reduction of work performance. Another possible effect on safety that cannot be neglected is that noise can produce masking effects that can disturbs the verbal communication with other persons and impedes the correct perception of warning signals. Such an effect can increase the risk of accidents at work. However, it is not acceptable either a completely silent environment because it can cause a sense of estrangement [185]. For these reasons, human exposure to noise should be evaluated in the field of safety in the workplace, but also in the domestic and private sphere, using indicators that take into account noise exposure even during the rest hours.

\subsubsection{Guidelines and Legislative Outline}

The legislative framework in the field of the human exposure to noise in work environments is very clear today. At the international level, the recommendations are given in the Physical Agents (Noise) Directives [186], where the minimum requirements for the protection of workers from risks arising from exposure to noise are provided. Such a directive was implemented by the European Union member states, including Italy with the law 81/2008 [47].

The assessment procedure of noise human exposure is indicated in the Technical Standard ISO 9612 [187] and is composed by the following phases: work analysis, selection of measurement strategy, measurements, error handling and uncertainty evaluations, equivalent exposure levels calculation, and presentation of results. In these procedures the choice of the most appropriate measurement strategy is extremely relevant in order to actually detect the effective human exposure and to estimate the results uncertainty. The indicators for this type of assessment are the daily exposure and the peak noise. Their action levels and limit values are given in [186] to ensure that appropriate actions are taken to guarantee the protection of workers. Personal hearing protection must be used when other controls cannot adequately reduce the noise exposures [188]. Hearing protection must be selected to reduce noise exposure without isolating the worker (overprotection), which may compromise safety.

In the Physical Agents (Noise) Directives [186] two exposure action values (EAV) and an exposure limit value are defined (Table 8). The two EAVs are the "upper exposure actions", and the "lower exposure actions" values. To the first correspond the noise exposure level, above which the employer must require the use of the personal protective equipment, and to the second correspond the noise exposure level above which the employer must provide the workers with the personal protective equipment (but it is not required to oblige their use). The exposure limit value represents the noise exposure level which must not be exceeded.

\subsubsection{Indicators}

It is important to note that sometimes, despite the continuous equivalent levels being lower than the limit values, exposure for a long time to noise characterized by particular frequency emissions (for example continuous noise at low frequencies) can still cause health problems. In this case, there is no risk of hearing loss, but rather a series of side effects (extra-auditory effects) such as headaches, dizziness, problems with the gastrointestinal system, increased respiratory rate, etc. The psychosocial effects are reflected on the modification of interpersonal relationships and on social relations. In addition to the Physical Agents Directives [186], international level guidelines (e.g., [189,190]) were published, in which indicators and the relative reference values, above which the first effects of noise on human health can begin, are provided (Table 8). 
Table 8. A collection of noise exposure indicators.

\begin{tabular}{|c|c|c|c|}
\hline Symbol & Indicator & Time Constant & Threshold $^{(2)}$ \\
\hline $\mathrm{L}_{\mathrm{EX}, 8 \mathrm{~h}}$ & Daily noise exposure level & $8 \mathrm{~h}$ & $80 / 85 / 87 \mathrm{~dB}(\mathrm{~A})^{(3)}$ \\
\hline$P_{\text {peak }}$ & Peak sound pressure & $125 \mathrm{~ms}$ & $135 / 137 / 140 \mathrm{~dB}(\mathrm{C})^{(3)}$ \\
\hline $\mathrm{L}_{\mathrm{Amax}}$ & $\begin{array}{l}\text { Maximum sound pressure level occurring in } \\
\text { an interval }\end{array}$ & $125 \mathrm{~ms}$ & $35 \mathrm{~dB}(\mathrm{~A})$ \\
\hline SEL & $\begin{array}{l}\text { Sound exposure level or sound pressure level } \\
\text { over an interval normalised to } 1 \mathrm{~s}\end{array}$ & $1 \mathrm{~s}$ & $53 \mathrm{~dB}(\mathrm{~A})$ \\
\hline $\mathrm{L}_{\text {day }}$ & Average sound pressure level over a 1 day & 12 or $16 \mathrm{~h}$ & \\
\hline $\mathrm{L}_{\text {night }}{ }^{(1)}$ & Average sound pressure level over 1 night & $8 \mathrm{~h}$ & $42 \mathrm{~dB}(\mathrm{~A})$ \\
\hline $\mathrm{L}_{24 \mathrm{~h}}$ & Average sound pressure level over a whole day & $24 \mathrm{~h}$ & \\
\hline $\mathrm{L}_{\mathrm{dn}}$ & $\begin{array}{l}\text { Average sound pressure level over a whole day } \\
\text { getting to the night values a penalty of } 10 \mathrm{~dB}\end{array}$ & $24 \mathrm{~h}$ & \\
\hline $\mathrm{L}_{\mathrm{den}}{ }^{(1)}$ & $\begin{array}{l}\text { Average sound pressure level over all days, } \\
\text { evening and nights in a year getting a penalty of } \\
5 \mathrm{~dB} \text { to the evening values and a penalty of } 10 \mathrm{~dB} \\
\text { for the night values }\end{array}$ & Year & $42 \mathrm{~dB}(\mathrm{~A})$ \\
\hline
\end{tabular}

\subsection{Acoustic Comfort}

\subsubsection{Overview}

The term "acoustic comfort" is not commonly used; a good acoustic environment is mainly associated with preventing the occurrence of discomfort. An acoustically comfortable building is able to isolate occupants from internal and external noise and at the same time to guarantee an environment acoustically appropriate for the activities carried out within it [191]. It can be defined as "a state of contentment with acoustic conditions" [192]. The acoustic sensation does not depend only on the sound pressure level but also on the sound frequency composition. The acoustic quality of an environment therefore depends on how the sound is propagated inside it (how the sound is absorbed and reflected by the surfaces), how the envelope structure is isolated from external noise, and how the sound coming from inside sources is treated. The acoustic comfort evaluations in workplaces are often undervalued, but especially in environments like offices where annoyance due to the noise can often cause mental stress and concentration loss, it is very important [44]. Very often, the acoustic comfort is considered adequate when the building envelope is sufficiently isolated from the noise coming from outside or adjacent environments (e.g., residential buildings). However, in many other cases, noise insulation is not sufficient to consider an environment acoustically comfortable and more detailed parameters should be used to obtain important information on the correct perception of sounds.

\subsubsection{Indicators}

In the literature, several indicators for the evaluation of the acoustic comfort in indoor environment are introduced. Such indicators can be divided into three wide groups: sound pressure levels, architectural acoustics, and building acoustics (Table 9).

The first group is composed of indicators related to the sound pressure levels established in an environment due to noise produced by a source located outside or inside the analyzed room.

The second group is composed of indicators which describe the acoustic transient and the quality of sound perception within the analyzed environment.

The third group is composed of indicators that do not describe directly the sound perception, but describe the sound insulation of buildings from noise coming from outside and adjacent environments and the levels of noise produced by the building services. 
Among the sound pressure levels indicators, the most widely used is the A-weighted equivalent sound pressure level $\mathrm{L}_{\text {eqA }}$. This takes into account the duration, the variation in time, and the frequency composition of the sound. [193]. However, this indicator may not always be the most suitable, while other more specific indicators can be preferable. Among the architectural acoustic indicators, the most common is the reverberation time $\left(\mathrm{RT}_{60}\right)$, although in literature many other indicators for detailed evaluations of the acoustic quality of rooms are present [194].

\subsubsection{Current Research Trends}

The evaluation of acoustic quality, especially in schools, is a very topical subject. One of the problems related to the evaluation of acoustic quality is that most indicators are obtained from field measurements or advanced simulations, and only a few indicators can be calculated in the design phase with simplified formulas. For this reason, topics of research concern the determination of equations based on an empirical basis (generally obtained using field measurement results) to correlate the indicators with the reverberation time, which can be calculated with simple and well-known equations. For example, in Italy, for the educational buildings, the speech transmission index (STI) must be verified during the design stage, but the calculus of STI requires field measurements or advanced simulations that are incompatible with the level of detail of the preliminary stage $[195,196]$.

Table 9. A collection of indicators for the evaluation of the acoustic comfort in indoor environment.

\begin{tabular}{|c|c|c|c|}
\hline Reference & Acoustic Comfort Metric & Symbol & Category \\
\hline $\begin{array}{c}{[197]} \\
{[198]} \\
{[199]} \\
{[200]} \\
{[201]} \\
{[202]} \\
{[203]} \\
{[204]} \\
{[205]} \\
{[206]} \\
{[207,208]} \\
{[209]} \\
{[210]} \\
{[211]}\end{array}$ & $\begin{array}{c}\text { A-weighted equivalent sound pressure level } \\
\text { A-weighted statistical levels } \\
\text { Linear equivalent sound pressure level } \\
\text { Balanced noise criterion } \\
\text { Combined noise index } \\
\text { Preferred noise criterion } \\
\text { Noise climate } \\
\text { Noise criterion curves } \\
\text { Noise pollution level } \\
\text { Noise rating curves } \\
\text { Office noise index } \\
\text { Quality assessment index } \\
\text { Room criterion } \\
\text { Room Criterion Mark II } \\
\text { Speech interference level } \\
\text { Stevens' loudness level } \\
\text { Zwicker's loudness level }\end{array}$ & $\begin{array}{c}\mathrm{L}_{\text {eqA }} \\
\mathrm{L}_{\mathrm{A} 90,} \mathrm{~L}_{\mathrm{A} 10}, \mathrm{~L}_{\mathrm{A} 5} \\
\mathrm{~L}_{\mathrm{eqlin}} \\
\mathrm{NCB} \\
\mathrm{CNI} \\
\mathrm{PNC} \\
\left(\mathrm{L}_{\mathrm{A} 10}-\mathrm{L}_{\mathrm{A} 90}\right) \\
\mathrm{NC} \\
\mathrm{LNP} \\
\mathrm{NR} \\
\text { ONI } \\
\text { QAI } \\
\text { RC } \\
\text { RC } \mathrm{markII} \\
\text { SIL } \\
\text { LLS } \\
\text { LLZ }\end{array}$ & Sound pressure level \\
\hline $\begin{array}{c}{[212]} \\
{[213]} \\
{[214]} \\
{[215]} \\
{[216,217]} \\
{[218]} \\
{[219-222]} \\
{[223]} \\
{[224]} \\
{[225]} \\
{[214]} \\
{[226]} \\
{[227]} \\
{[223,228]} \\
{[229]} \\
{[230]}\end{array}$ & $\begin{array}{c}\text { Articulation index } \\
\text { Articulation loss of consonants } \\
\text { Clarity index } \\
\text { Definition index } \\
\text { Early decay time } \\
\text { Late arriving sound/ Strength of the late arriving } \\
\text { Reverberation time } \\
\text { Room Acoustic Speech Transmission Index } \\
\text { Room gain } \\
\text { Signal to noise ratio } \\
\text { Speech clarity } \\
\text { Speech Intelligibility Index } \\
\text { Speech Transmission Index } \\
\text { Speech Transmission Index for Public Access } \\
\text { Strength value } \\
\text { Voice support }\end{array}$ & $\begin{array}{l}\text { AI } \\
\text { ALcons } \\
\mathrm{C}_{80} \\
\mathrm{D}_{50} \\
\mathrm{EDT} \\
\mathrm{G}_{\text {late }} \\
\mathrm{RT}_{30} \mathrm{RT}_{60} \\
\mathrm{RASTI}^{\mathrm{S}} \\
\mathrm{GR}_{\mathrm{G}, 0.5-2 \mathrm{kHz}} \\
\mathrm{S} / \mathrm{N} \\
\mathrm{C}_{50} \\
\mathrm{SII} \\
\mathrm{STI} \\
\mathrm{STIPA} \\
\mathrm{G} \\
\mathrm{ST}_{\mathrm{V}, 0.5-2 \mathrm{kHz}}\end{array}$ & $\begin{array}{l}\text { Architectural } \\
\text { acoustic }\end{array}$ \\
\hline $\begin{array}{l}{[231]} \\
{[232]} \\
{[232]} \\
{[233]} \\
{[234]} \\
{[235]}\end{array}$ & $\begin{array}{c}\text { Acoustic Performance index } \\
\text { Noise level produced by discontinuous service equipment } \\
\text { Noise level produced by continuous service equipment } \\
\text { Weighted normalized impact sound pressure level of floor } \\
\text { Weighted sound reduction index } \\
\text { Weighted standardized sound level difference of facade }\end{array}$ & $\begin{array}{c}\text { AP } \\
\mathrm{L}_{\mathrm{ic}} \\
\mathrm{L}_{\mathrm{id}} \\
\mathrm{L}_{\mathrm{nw}} \\
\mathrm{R}_{\mathrm{w}}^{\prime} \\
\mathrm{D}_{2 \mathrm{~m}, \mathrm{nt}, \mathrm{w}}\end{array}$ & Building acoustic \\
\hline
\end{tabular}


A second current research topic concerns the proposal of assessment methods of the overall acoustic quality that allow to evaluate the existing environments and to identify all the critical aspects that need improvements. These methods are generally based on Multicriteria analysis in order to combine the results of different indicators and obtain an overall rating [236,237]. In acoustics, only single parameter-based indicators exist, and for this reason, the multi-criteria approach is very interesting. This represents a potential overall assessment tool taking into account more indicators simultaneously. Until now, in fact, in acoustics, the individual indicators are determined and evaluated separately, and the combination of results is decided by the evaluator on the basis of subjective personal knowledge and sensitivity.

\section{Visual Environment}

Lighting has significant relevance on comfort and human life [238], with direct and indirect (non-visual) effects on the human body. The direct effects are related to visual performance (visual task activity) and visual comfort; the indirect effects are related to the possible consequences on safety and health. Traditionally, lighting assessment is limited to the assessment of illuminance in the task areas, however, there is a growing awareness of the effects of light on both health and the quality of human life. This is confirmed by new certification systems as the building certification system, developed by the International WELL Building Institute with the aim of "measure, monitor, and certify the performance of building features that impact health and well-being" [239].

\subsection{Non-Adequate Light Exposure}

\subsubsection{Overview}

Properly lighting is a basic need for visual performance and safety. Non-adequate lighting systems can cause problems with visual fatigue, as well as causing errors or possible accidents. In work environment special attention is focused on the video display terminal (VDT) workstations: electric lighting must guarantee adequate levels of illuminance for the reading and writing activities, but they should also favor a satisfactory contrast of luminance between the main object of view (the display) and the background in order to reduce visual fatigue $[240,241]$. For the video-terminal workstation, the asthenopic complaints are considered signs of visual discomfort. The most common visual discomfort markers are: red eyes, burning eyes, double vision, eye fatigue, blurred vision, headache, etc. [241-243]. Such effects together with inadequate lighting conditions can be related to the computer vision syndrome (CVS) [244]. At the end of 1980s, Bergqvist [245] revealed that eye discomfort and hand/wrist problems were associated with the work at the VDT workstation. Subsequently, several researches have further investigated the consequences of incorrect postures during VDT use [240-254] and the psychological effects of computer use [248]. Exposure to light is studied in relation to its photobiological effects, in particular the consequences of artificial optical radiations (AOR) emitted by light sources are evaluated. If in the past general lighting was considered risk exempt, recently, the advent of new LED sources has rekindled interest in this field, especially in the blue light hazard assessment [255]. In any case, the assessment of exposure to artificial optical radiation (not only produced by general lighting sources) is part of the physical agent, and it is included in the workers risk assessment procedures.

\subsubsection{Guidelines and Legislative Outline}

At the international level, Directive 89/654/EEC [256] includes an indication about lighting, and provides the requirements to guarantee health and safety in the workplaces. In [257] it is indicated that: "the workplace must have sufficient daylight and be equipped with devices that allow artificial lighting adequate to ensure the safety, health and welfare of workers". This directive was included in the Italian Law 81/2008 [47], where only rather general instructions (without specific limit values) are provided. 
Lighting not only affects visual performance and visual comfort, but also human health with so called "non-visual effects". In particular, it is necessary to evaluate human exposure to artificial optical radiation (AOR) emitted by light sources. Optical radiation regards the electromagnetic radiation in the wavelength range between $100 \mathrm{~nm}$ and $1 \mathrm{~mm}$. They are divided in: "ultraviolet" (UV), "infrared" (IR), and "visible light" (VIS) or more simply "light" radiation [258]. Biological effects of AOR affect the skin and eyes but systemic effects may also occur $[259,260]$. Regarding the optical radiation, the Directive 2006/25/CE [257] represents the basic guideline. This directive is adopted in the Italian Law 81/2008 [47], and for a series of wavelength ranges specifies indicators and limit values for the evaluation of the AOR workers exposure. On these issues, important documents are those published by the International Commission on Non-Ionizing Radiation Protection (ICNIRP) [261,262], and the recent international standards $[263,264]$.

\subsubsection{Indicators}

As indicated in the previous section, the national and international legislation does not provide limit values, and for this reason, the evaluations are generally qualitative and it is necessary to use the same indicators used for the evaluation of visual comfort (see Section 7.2).

The only field in which specific indicators are provided by the legislation is the artificial optical radiation (AOR). The AOR are included in the physical agents and it is required the evaluation for the workers' risk assessment. In Table 10, for each wavelength range, the exposure limit values, the type of hazard, and the action spectrum that must be used are indicated.

Table 10. Example of exposure limit values related to the artificial optical radiation.

\begin{tabular}{|c|c|c|c|c|c|}
\hline $\begin{array}{l}\text { Wavelength. } \\
\text { Range (nm) }\end{array}$ & Exposure Limit Values & Units & $\begin{array}{c}\text { Action } \\
\text { Spectrum }\end{array}$ & Hazard & Effects \\
\hline $\begin{array}{c}180 \div 400 \\
(\text { UVA, UVB, UVC) }\end{array}$ & $\begin{array}{c}\mathrm{H}_{\mathrm{EFF}}=30 \\
\text { Daily value }(8 \mathrm{~h})\end{array}$ & $\mathrm{J} / \mathrm{m}^{2}$ & $S(\lambda)$ & Actinic UV & $\begin{array}{c}\text { Eye: Photokeratitis; } \\
\text { Conjuctivitis; } \\
\text { Cataractogenesis. Skin: } \\
\text { Elastosis }\end{array}$ \\
\hline $\begin{array}{l}315 \div 400 \\
\text { (UVA) }\end{array}$ & $\begin{array}{c}\mathrm{H}_{\mathrm{UVA}}=10^{4} \\
\text { Daily value }(8 \mathrm{~h})\end{array}$ & $\mathrm{J} / \mathrm{m}^{2}$ & & UVA & Eye: Cataractogenesis \\
\hline \multirow{4}{*}{$\begin{array}{l}300 \div 700 \\
\text { (Blue Light) }\end{array}$} & $\begin{array}{c}\mathrm{L}_{\mathrm{B}}=10^{6} \cdot t^{-1} \\
\text { for } t \leq 10,000 \mathrm{~s}\end{array}$ & \multirow[t]{2}{*}{$\mathrm{W} / \mathrm{m}^{2} \cdot \mathrm{sr}$} & \multirow[t]{2}{*}{$\mathrm{B}(\lambda)$} & \multirow{2}{*}{$\begin{array}{l}\text { Retinal Blue-Light } \\
\text { small source }\end{array}$} & \multirow{4}{*}{ Eye: Photoretinitis } \\
\hline & $\begin{array}{c}\mathrm{L}_{\mathrm{B}}=100 \\
\text { for } t>10,000 \mathrm{~s}\end{array}$ & & & & \\
\hline & $\begin{array}{c}E_{\mathrm{B}}=100 \cdot t^{-1} \\
\text { for } t \leq 10,000 \mathrm{~s}\end{array}$ & \multirow[t]{2}{*}{$\mathrm{W} / \mathrm{m}^{2}$} & \multirow[t]{2}{*}{$B(\lambda)$} & \multirow[t]{2}{*}{$\begin{array}{l}\text { Retinal Blue-Light } \\
\text { small source }\end{array}$} & \\
\hline & $\begin{array}{c}\mathrm{E}_{\mathrm{B}}=0.01 \\
\text { for } t>10,000 \mathrm{~s}\end{array}$ & & & & \\
\hline \multirow{3}{*}{$\begin{array}{c}380 \div 1400 \\
\text { (Visible, IRA) }\end{array}$} & $\begin{array}{c}\mathrm{L}_{\mathrm{R}}=\left(2.8 \cdot 10^{7}\right) \cdot \mathrm{C}_{\alpha}{ }^{-1} \\
\text { for } t>10 \mathrm{~s}\end{array}$ & \multirow{6}{*}{$\mathrm{W} / \mathrm{m}^{2} \cdot \mathrm{sr}$} & \multirow{3}{*}{$\mathrm{R}(\lambda)$} & \multirow{3}{*}{ Retinal thermal } & \multirow{3}{*}{ Eye: Retinal burn } \\
\hline & $\begin{array}{l}\mathrm{L}_{\mathrm{R}}=\left(5 \times 10^{7}\right) \cdot \mathrm{C}_{\alpha}{ }^{-1} \cdot t^{-0.25} \\
\quad \text { for } 10 \mu \mathrm{s} \leq t \leq 10 \mathrm{~s}\end{array}$ & & & & \\
\hline & $\begin{aligned} \mathrm{L}_{\mathrm{R}}= & \left(8.89 \times 10^{8}\right) \cdot \mathrm{C}_{\alpha}{ }^{-1} \\
& \text { for } t<10 \mu \mathrm{s}\end{aligned}$ & & & & \\
\hline \multirow{3}{*}{$\begin{array}{l}780 \div 1400 \\
\quad(\text { IRA })\end{array}$} & $\begin{array}{c}\mathrm{L}_{\mathrm{R}}=\left(6 \times 10^{6}\right) \mathrm{C}_{\alpha}{ }^{-1} \\
\text { for } t>10 \mathrm{~s}\end{array}$ & & \multirow{3}{*}{$\mathrm{R}(\lambda)$} & \multirow{3}{*}{$\begin{array}{l}\text { Retinal thermal-weak } \\
\text { visual stimulus }\end{array}$} & \multirow{3}{*}{ Eye: Retinal burn } \\
\hline & $\begin{array}{l}\mathrm{L}_{\mathrm{R}}=\left(5 \times 10^{7}\right) \cdot \mathrm{C}_{\alpha}{ }^{-1} \cdot t^{-0.25} \\
\quad \text { for } 10 \mu \mathrm{s} \leq t \leq 10 \mathrm{~s}\end{array}$ & & & & \\
\hline & $\begin{aligned} \mathrm{L}_{\mathrm{R}}= & \left(8.89 \times 10^{8}\right) \mathrm{C}_{\alpha}{ }^{-1} \\
& \text { for } t<10 \mu \mathrm{s}\end{aligned}$ & & & & \\
\hline \multirow[t]{2}{*}{$\begin{array}{l}780 \div 3000 \\
(\text { IRA, IRB) }\end{array}$} & $\begin{array}{l}\mathrm{E}_{\mathrm{IR}}=18,000 \cdot t^{-0.75} \\
\quad \text { for } t \leq 1000 \mathrm{~s}\end{array}$ & \multirow[t]{2}{*}{$\mathrm{W} / \mathrm{m}^{2}$} & & \multirow{2}{*}{$\begin{array}{l}\text { Infrared radiation } \\
\text { eye }\end{array}$} & \multirow[t]{2}{*}{$\begin{array}{l}\text { Eye: Cornea burn; } \\
\text { Cataractogenesis }\end{array}$} \\
\hline & $\begin{array}{c}E_{I R}=100 \\
\text { for } t>1000 s\end{array}$ & & & & \\
\hline $\begin{array}{c}380 \div 3000 \\
(\text { Visible, IRA, IRB) }\end{array}$ & $\begin{array}{c}\mathrm{H}_{\mathrm{SKIN}}=20,000 \cdot \mathrm{t}^{0.25} \\
\text { for } t<10 \mathrm{~s}\end{array}$ & $\mathrm{~J} / \mathrm{m}^{2}$ & & Thermal skin & Skin: Skin burn \\
\hline
\end{tabular}




\subsection{Visual Comfort}

\subsubsection{Overview}

In EN 12665, visual comfort is defined as "a subjective condition of visual well-being induced by the visual environment" [265]. Lighting, daylighting, and the use of colors have a significant impact on the perception of the environment, and can affect both physical and mental well-being. Visual comfort was commonly studied through the evaluation of some factors that characterize the relationship between human needs and the enlightened environment [30].

In inadequate lighting conditions, visual discomfort may not be immediately perceived due to the effect of adaptation of the visual apparatus, but may affect work performance or lead to visual fatigue.

\subsubsection{Indicators}

The indicators for the visual comfort evaluation can be separated in four groups: amount of light, color rendering, daylight availability, and glare. For each group, a collection of indicators is proposed as reported in Table 11.

Table 11. A collection of visual comfort indicators.

\begin{tabular}{|c|c|c|c|}
\hline Reference & Visual Comfort Metric & Symbol & Category \\
\hline [266] & Illuminance & E (lx) & \multirow{5}{*}{ Amount of light } \\
\hline [266] & Illuminance uniformity & U & \\
\hline [266] & Luminance & $\mathrm{L}\left(\mathrm{cd} / \mathrm{m}^{2}\right)$ & \\
\hline [266] & Luminance ratio & LR & \\
\hline [267] & Scotopic/Photopic ratio & $\mathrm{S} / \mathrm{P}$ ratio & \\
\hline [268] & Color Discrimination Index & CDI & \multirow{10}{*}{ Color rendition } \\
\hline [269] & Color Preference Index & CPI & \\
\hline [270] & Color Rendering Capacity & CRC & \\
\hline [266] & Color Rendering Index & CRI & \\
\hline [271] & Color Quality Scale & CQS & \\
\hline [272] & Feeling of contrast Index & FCI & \\
\hline [273] & Flattery Index & & \\
\hline [274] & Gamut Area Index & GAI & \\
\hline [275] & Memory color quality metric & $\mathrm{S}(\mathrm{a})$ & \\
\hline [276] & Pointer's new color rendering index & & \\
\hline [277] & Annual Sunlight Exposure & ASE & \multirow{8}{*}{$\begin{array}{c}\text { Daylight } \\
\text { availability }\end{array}$} \\
\hline [278] & Continuous Daylight Autonomy & $\mathrm{cDA}$ & \\
\hline [279] & Daylight Autonomy & DA & \\
\hline [280] & Daylight Factor & DF & \\
\hline [281] & Frequency of Visual Comfort & FVC & \\
\hline [281] & Intensity Visual Discomfort & IVD & \\
\hline [277] & Spatial Daylight Autonomy & sDA & \\
\hline [282] & Useful Daylight Illuminance & UDI & \\
\hline [283] & British Glare Index & & \multirow{14}{*}{ Glare } \\
\hline [284] & CIE Glare Index & CGI & \\
\hline [285] & Discomfort Glare Index & DGI & \\
\hline [286] & Discomfort Glare Probability & DGP & \\
\hline [287] & Enhanced simplified Discomfort Glare Probability & eDGPs & \\
\hline$[284,288]$ & Great-room Glare Rating & GGR & \\
\hline [289] & Hviid simplified Discomfort Glare Probability & DGPs $_{\text {Hviid }}$ & \\
\hline [290] & J-index & $\mathrm{J}$ & \\
\hline [291] & New Discomfort Glare Index & $\mathrm{DGI}_{\mathrm{N}}$ & \\
\hline [292] & Predicted Glare Sensation Vote & PGSV & \\
\hline$[293,294]$ & Unified Glare Rating & UGR & \\
\hline$[284,288]$ & Unified Glare Rating for small sources & $\mathrm{UGR}_{\text {small }}$ & \\
\hline [295] & Visual Comfort Probability & VCP & \\
\hline [296] & Wienold Simplified Discomfort Glare Probability & DGPs Wienold & \\
\hline
\end{tabular}

Amount of light concerns the quantitative lighting parameters commonly used for the lighting design. They are generally used to describe the performance of electric lighting systems, or in other 
words, if the lighting systems allow creating sufficient light conditions. In this group, the most used indicator is the illuminance over the task areas.

Color rendition concerns the property of a light source to return the colors correctly. In this group the most used indicator is the color rendering index (CRI). Nevertheless, with the diffusion of LED sources, this indicator is no longer considered the most reliable. New indicators are now under investigation, as for example the color quality scale [271] and the memory color quality metric [275].

Daylight availability concerns the amount of daylight that can be exploited in an environment. This group includes quantitative indicators aimed at assessing the penetration of daylight into the environment, while some other indicators make it possible to carry out assessments on extended time profiles and to estimate the reduction in yearly electricity consumption due to the lower use of electric lighting. In this group, the most used indicator is the daylight factor (DF). However the improvement of simulation software allows to evaluate the daylight availability day by day in real condition (Climate Based daylight modelling software). With the development of such new software the creation of new indicators (e.g., useful daylight illuminance, daylight autonomy, etc.) was possible. These new indicators have great potentialities, because they allow also for optimizing the use of building automation control systems (BACS) and their use is rapidly becoming more and more common.

Glare concerns the conditions of vision in which, caused by an unsuitable luminance distribution, there is discomfort, annoyance or a reduction in visual performance and visibility. In this group, the most used indicator is the unified glare rating (UGR); however, in the literature, many indicators for the evaluation of glare from different sources were proposed.

In lighting, as in acoustics, overall indicators do not exist, and visual comfort must be evaluated as a synergic combination of the results of more indicators properly chosen for the analyzed environment. In these evaluations, at least one indicator is generally used for each category, while the benchmark values depend on the specific visual tasks carried out.

\subsubsection{Current Research Trends}

The discovery of new photoreceptors inside the human vision system able to influence the human body physiological functions has opened a new branch [297]. These new photoreceptors, that are called intrinsically photoreceptive retinal ganglion cells (ipRGCs) serve no visual function [298].

It is currently recognized that exposure to insufficient or inappropriate lighting scenarios can bother the standard human rhythms, which can have negative consequences for performance but also for health [299]. The development of new circadian metrics is based on scientific information and expert judgments related to the duration of the exposures, time of the day, intensity, light spectrum, and history of light exposures. [300]. In order to evaluate the potential effects of the light sources on the circadian rhythms, it was necessary to quantify the light exposure in biologically meaningful units [301-307]. Until now, a consensus on the appropriate minimum light exposure threshold to ensure effective circadian stimulus in buildings has not yet obtained. The WELL Building Standard's "Circadian Lighting Design" implements a minimum threshold of 250 Equivalent Melanopic Lux (EML), which must be available for at least $4 \mathrm{~h}$ each day. Such requirement can be met with daylight, artificial light (exclusively), or a combination of both sources [239,298,306]. Figueiro et al. [308] recommend exposure to a "circadian stimulus (CS) of 0.3 or greater at the eye for at least $1 \mathrm{~h}$ in the early part of the day (equivalent to 180 lux, D65)".

In any case, the relationships between spectral distribution, duration, timing, and intensity of light exposure for optimal circadian health should be further clarified by the research community.

\section{Conclusive Remarks}

The main aim of this review is to create a comprehensive framework on the indicators for the health and comfort evaluations in indoor environments that is missing today in the scientific literature. Indeed, until now, only review papers that collect indicators of single environmental factors were published. 
Occupants' health and comfort represent two basic needs in indoor environment and, although their assessments are characterized by two very different approaches, in some cases, the selection of the proper indicators is not always so obvious. In fact, for the thermal environment, indoor air quality, and lighting, selection is not so obvious and some indicators are commonly proposed for both health risk and comfort evaluation.

Concerning the thermal environment, in the literature there are numerous indicators but the distinction between comfort and thermal stress indicators is not always clear. This means that, in this field, the boundary between health and comfort is particularly subtle and it is not always easy to distinguish the two approaches. Among the thermal indicators, many can be considered "overall" indicators because they are based on two or more parameters and provide direct information about the human thermal perception. In this paper, 35 heat stress indicators and 46 thermal comfort indicators were collected. Despite the large number of indicators, the most used are historically the PMV for the evaluation of thermal comfort, and the WBGT for the evaluation of thermal stress. Today, the use of adaptive comfort models combined with software simulations that can implement climate-based model are much more frequent, however there are still doubts about how these systems can estimate the actual behavior of the users (strength of the post-occupancy evaluation methods).

Concerning the air quality, few indicators were proposed, however, it is very common to evaluate the single air pollutant concentration and compare the results with threshold limit values more or less restrictive depending on the type of evaluation (i.e., minimum safety evaluation or high levels of air quality). Although the indoor environments are often characterized by pollutants concentrations higher than the external environments (where detailed monitoring takes place), only a small number of indoor pollutants can be commonly measured. In this review, nine indicators for the air quality assessment and the limit values of 17 air pollutants are reported. Given the difficulty of measuring all the indoor air pollutants and linking them to human perception, overall indicators similar to those used for the assessment of thermal comfort, were recently proposed. Such indicators are based on subjective evaluations, but at an international level, it is not yet a consensus on which indicator is most correct to use.

Concerning acoustics, the separation between health and comfort is more evident, because human exposure to noise in work environment is clearly defined in the physical agent risk assessment directive. However, it is important to observe that there are many cases where, despite compliance with the limit values, the noise exposure can lead to a series of extra-hearing side effects that must be analyzed in relation to other typical aspects of work-related stress. In addition, people are continuously exposed to noise, even when they sleep; therefore, also the noise level exposures during the whole day and/or the night-time are relevant. Regarding acoustic comfort, 39 indicators classified into three different groups (sound pressure levels, architectural acoustics, and building acoustics) are collected. Among these, overall indicators based on more parameters do not exist, so it is not possible to directly obtain information about acoustic comfort perception. For this reason, for a complete acoustic comfort assessment, it is necessary to use sets of indicators suitably chosen according to the type of environment analyzed.

Concerning lighting, it must be considered that visual and non-visual effects are related to the use of lighting systems. The visual effects are directly related to the visual performance and they are the first analyzed when the lighting of an indoor environment is evaluated. The non-visual effects should be considered because they can affect the occupants health and well-being. For the assessment of occupants' health, the literature focused on two aspects: the asthenopic effects due to the use of video terminal equipment and the exposure to artificial optical radiation. For the evaluation of the asthenopic effects, there are no limit values or specific indicators, but qualitative assessments are necessary. Artificial optical radiation is included in the physical agents assessment and characterized by a series of indicators according to the different wavelength ranges. For the assessment of visual comfort, 37 indicators are identified and divided into 4 groups (amount of light, glare, color rendition, daylight availability). In lighting, especially for the evaluation of the daylight availability, a rapid 
evolution connected to the development of software that allows simulation in real climate conditions is under investigation. New daylight indicators allow to combine the evaluation of lighting with the related lighting systems energy consumption, and to estimate the energy consumption reduction due to the optimization of daylight availability.

The growing interest in the IEQ, which is also reflected in the launch of new building certification systems, has led to a growing need for new overall indicators, sets of indicators, or standardized assessment procedures approved at international level. These indicators can allow to evaluate the human perception of the single environmental factor, as well as to carry out overall evaluations in which the four environmental factors are simultaneously taken into consideration. In this paper, the authors have tried to collect and organize a wide range of indicators for assessing the health and comfort of indoor environments. These indicators are not often clearly identified in the evaluation processes, but the interest in these aspects is increasing and clear information to allow the selection of the most appropriate indicators is necessary.

The present review paper represents the state of the art of the indicators of indoor environmental factors. It should be pointed out that the overall assessments of IEQ could include a selection of the indicators proposed in the literature or the proposal of new indicators that take into account several factors simultaneously. In any case, as suggested in [1], it is necessary to verify that all the aspects analyzed reach satisfactory levels, but also that the adverse impact of the interaction between these aspects is as limited as possible. In any case, when global assessments are carried out, it must be taken into consideration that the global acceptance of an environment does not depend exclusively on the achievement of adequate levels of comfort related to the four environmental factors. This is also influenced by other aspects, such as the level of expectation, the adaptation capacity, personal subjective preferences, as well as the psychological and physiological conditions of the occupants.

Author Contributions: All the authors contributed in equal parts to the research activity and to the paper writing. All authors have read and agreed to the published version of the manuscript.

Funding: This research received no external funding.

Conflicts of Interest: The authors declare no conflict of interest.

\section{References}

1. American Society of Heating, Refrigerating and Air-Conditioning Engineering (ASHRAE). Guideline 10P, Interactions Affecting the Achievement of Acceptable Indoor Environments; ASHRAE: Atlanta, GA, USA, 2016.

2. Pinto, S.; Fumincelli, L.; Mazzo, A.; Caldeira, S.; Martins, J.C. Comfort, well-being and quality of life: Discussion of the differences and similarities among the concepts. Porto Biomed. J. 2017, 2, 6-12. [CrossRef]

3. Directive (EU). 2018/844 of the European Parliament and of the Council of 30 May 2018 amending Directive 2010/31/EU on the Energy Performance of Buildings and Directive 2012/27/EU on Energy Efficiency; EU: Brussels, Belgium, 2018.

4. Directive 2012/27/EU of the European Parliament and of the Council of 25 October 2012 on Energy Efficiency, Amending Directives 2009/125/EC and 2010/30/EU and Repealing Directives 2004/8/EC and 2006/32/EC. Available online: https://eur-lex.europa.eu/legal-content/EN/TXT/?uri=celex\%3A32012L0027 (accessed on 7 January 2020).

5. Directive 2010/31/EU of the European Parliament and of the Council of 19 May 2010 on The Energy Performance of Buildings. Available online: https://eur-lex.europa.eu/legal-content/EN/TXT/?uri=CELEX\% 3A32010L0031 (accessed on 7 January 2020).

6. Directive 2002/91/EC of the European Parliament and of the Council of 16 December 2002 on the energy performance of buildings. Available online: https://eur-lex.europa.eu/legal-content/EN/TXT/?uri= LEGISSUM\%3A127042 (accessed on 7 January 2020).

7. Bluyssen, P.M. Towards new methods and ways to create healthy and comfortable buildings. Build. Environ. 2010, 45, 808-818. [CrossRef]

8. World Health Organization (WHO). Definition of Health. Available online: http://www.who.int/about/ definition/en/print.html (accessed on 12 March 2019). 
9. Commission of the European Communities. White Paper-Together for Health. A Strategic Approach for the EU 2008-2013; Commission of the European Communities: Brussels, Belgium, 2007; Available online: https://ec.europa.eu/health/ph_overview/Documents/strategy_wp_en.pdf (accessed on 6 June 2019).

10. Tang, H.; Ding, Y.; Singer, B. Interactions and comprehensive effect of indoor environmental quality factors on occupant satisfaction. Build. Environ. 2020, 167, 106462. [CrossRef]

11. Shan, A.; Nissa Melina, A.; Yang, E.H. Impact of indoor environmental quality on students' wellbeing and performance in educational building through life cycle costing perspective. J. Clean. Prod. 2018, 204, $298-309$. [CrossRef]

12. Lee, E. Indoor environmental quality (IEQ) of LEED-certified home: Importance-performance analysis (IPA). Build. Environ. 2019, 149, 571-581. [CrossRef]

13. Geng, Y.; Lin, B.; Yu, J.; Zhou, H.; Ji, W.; Chen, H.; Zhang, Z.; Zhu, Y. Indoor environmental quality of green office buildings in China: Large-scale and long-term measurement. Build. Environ. 2019, 150, 266-280. [CrossRef]

14. Anand, P.; Cheong, D.; Sekhar, C.; Santamouris, M.; Kondepudi, S. Energy saving estimation for plug and lighting load using occupancy analysis. Renew. Energy 2019, 143, 1143-1161. [CrossRef]

15. European Committee for Standardization. EN 15251: Indoor Environmental Input Parameters for Design and Assessment of Energy Performance of Buildings Addressing Indoor Air Quality, Thermal Environment, Lighting and Acoustics; European Committee for Standardization: Brussels, Belgium, 2007.

16. European Committee for Standardization. Part 1: Indoor Environmental Input Parameters for Design and Assessment of Energy Performance of Buildings Addressing Indoor Air Quality, Thermal Environment Lighting and Acoustics. Module M1-6. In EN 16798-1 Energy Performance of Buildings. Ventilation for Buildings; European Committee for Standardization: Brussels, Belgium, 2019.

17. European Committee for Standardization. PD CEN/TR 16798-2 Energy Performance of Buildings. In Ventilation for Buildings; Part 2: Interpretation of the Requirements in EN 16798-1. Indoor Environmental Input Parameters for Design and Assessment of Energy Performance of Buildings Addressing Indoor Air Quality, Thermal Environment, Lighting and Acoustics. Module M1-6; European Committee for Standardization: Brussels, Belgium, 2019.

18. Anand, P.; Deb, C.; Alur, R. A simplified tool for building layout design based on thermal comfort simulations. Front. Archit. Res. 2017, 6, 218-230. [CrossRef]

19. Redlich, C.A.; Sparer, J.; Cullen, M.R. Sick-building syndrome. Lancet 1997, 349, 1013-1016. [CrossRef]

20. Burge, P.S. Sick Building Syndrome. Occup. Environ. Med. 2004, 61, 185-190. [CrossRef]

21. Ghaffarianhoseini, A.; AlWaer, H.; Omrany, H.; Ghaffarianhoseini, A.; Alalouch, C.; Clements-Croome, D.; Tookey, J. Sick building syndrome: Are we doing enough? Archit. Sci. Rev. 2018, 61, 99-121. [CrossRef]

22. World Health Organization (WHO). Indoor Air Pollutants: Exposure and Health Effects; EURO Reports and Studies 78: 1-42.; WHO: Geneva, Switzerland, 1983.

23. Kamaruzzaman, S.; Sabrani, N.A. The Effect of Indoor Air Quality (IAQ) Towards Occupants' Psychological Performance in Office Buildings. J. Rekabentuk Dan Binaan 2011, 4, 49-61.

24. Runeson-Broberg, R.; Norbäck, D. Sick Building Syndrome (SBS) and Sick House Syndrome (SHS) in Relation to Psychosocial Stress at Work in the Swedish Workforce. Int. Arch. Occup. Environ. Health 2013, 86, 915-922. [CrossRef] [PubMed]

25. De Freitas, C.R.; Grigorieva, E.A. A comprehensive catalogue and classification of human thermal climate indices. Int. J. Biometeorol. 2015, 59, 109-120. [CrossRef]

26. D'Ambrosio Alfano, F.R.; Palella, B.I.; Riccio, G. Thermal Environment Assessment Reliability Using Temperature-Humidity Indices. Ind. Health 2011, 49, 95-106. [CrossRef]

27. Carlucci, S.; Pagliano, L. A review of indices for the long-term evaluation of the general thermal comfort conditions in buildings. Energy Build. 2012, 53, 194-205. [CrossRef]

28. Beshir, M.Y.; Ramsey, J.D. Heat stress indices: A review paper. Int. J. Ind. Ergon. 1988, 3, 89-102. [CrossRef]

29. Djongyang, N.; Tchinda, R.; Njomo, D. Thermal comfort: A review paper. Renew. Sustain. Energy Rev. 2010, 14, 2626-2640. [CrossRef]

30. Carlucci, S.; Causone, F.; De Rosa, F.; Pagliano, L. A review of indices for assessing visual comfort with a view to their use in optimization processes to support building integrated design. Renew. Sustain. Energy Rev. 2015, 47, 1016-1033. [CrossRef]

31. Sundell, J. On the history of indoor air quality and health. Indoor Air 2004, 14, 51-58. [CrossRef] 
32. European Agency of Safety and Health at Work (EU-OSHA). Well-Being at Work: Creating a Positive Work Environment; EU-OSHA: Luxembourg, 2013.

33. Institution of Occupational Safety and Health (IOSH). Working Well. Guidance on Promoting Health and Wellbeing at Work; IOSH: Leicestershire, UK, 2018.

34. Public Health Agency (HSC). Health and Wellbeing at Work: A Resource Guide; HSC: Belfast, Northern Ireland, 2017.

35. Anand, P.; Sekhar, C.; Cheong, D.; Santamouris, M.; Kondepudi, S. Occupancy-based zone-level VAV system control implications on thermal comfort, ventilation, indoor air quality and building energy efficiency. Energy Build. 2019, 204, 109473. [CrossRef]

36. American Society of Heating, Refrigerating and Air-Conditioning Engineering (ASHRAE). "TC 1.6 Terminology", Atlanta, USA. Available online: http://tc0106.ashraetcs.org/ (accessed on 21 January 2019).

37. Fisk, W.J. Health and productivity gains from better indoor environments and their relationship with building energy efficiency. Annu. Rev. Energy Environ. 2000, 25, 537-566. [CrossRef]

38. Andersson, J.; Boerstra, A.; Clements-Croome, D.; Fitzner, K.; Hanssen, S.O. Indoor Climates and Productivity in Offices; Wargocki, P., Seppänen, O., Eds.; REHVA: Ixelles, Belgium, 2006; Volume 6.

39. Seppanen, O.A. Association of ventilation rates and $\mathrm{CO} 2$ concentrations with health and other responses in commercial and institutional buildings. Indoor Air 1999, 9, 226-252. [CrossRef]

40. De Giuli, V.; Da Pos, O.; De Carli, M. Indoor environmental quality and pupil perception in Italian primary schools. Build. Environ. 2012, 56, 335-345. [CrossRef]

41. Parsons, K.C. Human Thermal Environments: The Effects of Hot, Moderate, and Cold Environments on Human Health, Comfort and Performance, 3nd ed.; Taylor and Francis: London, UK, 2014.

42. Epstein, Y.; Moras, D.S. Thermal Comfort and the Heat Stress Indices. Ind. Health 2006, 44, 388-398. [CrossRef] [PubMed]

43. Morgado, M.; Talaia, M.; Teixeira, L. A new simplified model for evaluating thermal environment and thermal sensation: An approach to avoid occupational disorders. Int. J. Ind. Ergon. 2017, 60, 3-13. [CrossRef]

44. European Agency for Occupational Health and Safety at Work (EU-OSHA)-OSHwiki. Available online: http:\$delimiter"026E30F\$\$delimiter"026E30F\$oshwiki.eu (accessed on 12 March 2019).

45. Council Directive 89/391/EEC of 12 June 1989 on the Introduction of Measures to Encourage Improvements in the Safety and Health of Workers at Work. Available online: https://eur-lex.europa.eu/legal-content/EN/ TXT/?uri=CELEX:52006PC0390 (accessed on 7 January 2020).

46. Workplace Safety \& Health Division of the Manitoba Government. Guideline for Thermal Stress; Workplace Safety \& Health Division of the Manitoba Government: Winnipeg, MB, Canada, 2007. Available online: https://www.gov.mb.ca/labour/safety/ (accessed on 21 January 2019).

47. Italian Legislative Decree, No. 81/2008 "Code on Health and Safety Protection of Employees in the workplace", implementation of Article 1 of Law 3 August 2007, No 123 on Health and Safety in the workplaces. Available online: https://www.ispettorato.gov.it/it-it/Documenti-Norme/Documents/Testo-Unico-Dlgs-81-08-edizionedi-luglio-2018.pdf (accessed on 7 January 2020).

48. Malchaire, J.B.; Gebhardt, H.J.; Piette, A. Strategy for evaluation and prevention of risk due to work in thermal environment. Ann. Occup. Hyg. 1999, 43, 367-376. [CrossRef]

49. Malchaire, J.B. Occupational heat stress assessment by the Predicted Heat Strain model. Ind. Health 2006, 44, 380-387. [CrossRef]

50. Palella, B.I.; Quaranta, F.; Riccio, G. On the management and prevention of heat stress for crews on board ships. Ocean Eng. 2016, 112, 277-286. [CrossRef]

51. Taleghani, M.; Tenpierik, M.; Kurvers, S.; van den Dobbelsteen, A. A review into thermal comfort in buildings. Renew. Sustain. Energy Rev. 2013, 26, 201-215. [CrossRef]

52. Yaglou, C.P.; Minard, D. Control of heat casualties at military training centers. Am. Med. Assoc. Arch. Ind. Health 1957, 16, 302-316.

53. Siple, P.A.; Passel, C.F. Measurement of dry atmospheric cooling in subfreezing temperatures. Proc. Am. Phil. Soc. 1945, 89, 177-199. [CrossRef]

54. Holmer, I. Required Clothing Insulation (IREQ) as an Analytical Index of the Cold Stress. Ashrae Trans. 1984, 90, 1116-1128.

55. De Freitas, C.R.; Symon, L.V. A bioclimatic index of human survival times in the Antarctic. Polar Rec. 1987, 23, 651-659. [CrossRef] 
56. Shitzer, A. Wind-chill-equivalent temperatures: Regarding the impact due to the variability of the environmental convective heat transfer coefficient. Int. J. Biometeorol. 2006, 50, 224-232. [CrossRef]

57. International Organization for Standardization. ISO 11079. Ergonomics of the Thermal Environment-Determination and Interpretation of Cold Stress When Using Required Clothing Insulation (IREQ) and Local Cooling Effects; International Organization for Standardization: Geneve, Switzerland, 2007.

58. Robinson, S.; Turrell, E.S.; Gerking, S.D. Physiologically equivalent conditions of air temperature and humidity. Am. J. Physiol. 1945, 143, 21-32. [CrossRef]

59. McArdle, B.; Dunham, W.; Holling, H.E.; Ladel, W.S.S.; Scott, J.W.; Thomson, M.L.; Weiner, J.S. The Prediction of the Physiological Effects of Warm and Hot Environments. Available online: https://www.scienceopen. com/document?vid=f0cf60ca-b22b-4615-be54-548ad606fd56 (accessed on 7 January 2020).

60. Belding, H.S.; Hatch, T.F. Index for evaluating heat stress in terms of resulting physiological strain. Heat. Pip. Air Condit. 1955, 27, 129-136.

61. Lee, D.H.K. Proprioclimates of Man and Domestic Animals. Climatology, Arid Zone Research-X, UNESCO. 1958, p. 102. Available online: https://unesdoc.unesco.org/ark:/48223/pf0000179751 (accessed on 6 June 2019).

62. Lally, V.E.; Watson, B.F. Humiture revisited. Weatherwise 1960, 13, 254-256. [CrossRef]

63. Givoni, B. The influence of work and environmental conditions on the physiological responses and thermal equilibrium of man. Arid Zone Res. 1962, 24, 199-204.

64. McKarns, J.S.; Brief, R.S. Nomographs give refined estimate of heat stress index. J. Occup. Med. 1966, 8, 557.

65. Fuller, F.H.; Brouha, L. New engineering methods for evaluating the job environment. Ashrae J. 1966, 8, 39-52.

66. Lind, A.R. Effect of individual variation on upper limit of perspective zone of climates. J. Appl. Physiol. 1970, 28, 57-62. [CrossRef] [PubMed]

67. Botsford, J.H. A wet globe thermometer for environmental heat measurement. Am. Ind. Hyg. Assoc. J. 1971, 32, 1-10. [CrossRef] [PubMed]

68. Kerslake, D.M. The Stress of Hot Environment; Cambridge University Press: Cambridge, UK, 1972.

69. Givoni, B.; Pandolf, R.R. Predicting heart rate response to work, environment and clothing. J. Appl. Physiol. 1973, 34, 201-204. [CrossRef] [PubMed]

70. Gonzalez, R.R.; Bergulnd, L.G.; Gagge, A.P. Indices of thermoregulatory strain for moderate exercise in the heat. J. Appl. Physiol. 1978, 44, 889-899. [CrossRef] [PubMed]

71. Nunneley, S.H.; Stribley, F. Fighter index of thermal stress (FITS): Guidance for hot-weather aircraft operations. Aviat. Space Environ. Med. 1979, 50, 639-642. [PubMed]

72. Kamon, E.; Ryan, C. Effective heat strain index using pocket computer. Am. Ind. Hyg. Assoc. J. 1981, 42, 611-615. [CrossRef]

73. Shapiro, Y.; Pandolf, K.B.; Goldman, R.F. Predicting sweat loss response to exercise, environment and clothing. Eur. J. Appl. Physiol. Occup. Physiol. 1982, 48, 83-96. [CrossRef]

74. Höppe, P. Die Energiebilanz des Menschen. Ph.D. Thesis, University of München, Munich, Germany, 1984.

75. De Freitas, C.R. Assessment of human bioclimate based on thermal response. Int. J. Biometeorol. 1985, 29, 97-119. [CrossRef]

76. Frank, A.; Moran, D.; Epstein, Y.; Belokopytov, M.; Shapiro, Y. The Estimation of Heat Tolerance by a New Cumulative Heat Strain Index. Available online: https://www.lboro.ac.uk/microsites/lds/EEC/ICEE/ textsearch/1996/Frank-1996.pdf (accessed on 7 January 2020).

77. Moran, D.S.; Shitzer, A.; Pandolf, K.B. A physiological strain index to evaluate heat stress. Am. J. Physiol. 1998, 275, 129-134. [CrossRef]

78. International Standard Organization (ISO). Hot Environments-Analytical Determination and Interpretation of Thermal Stress Using Calculation of Required Sweat Rate; ISO: Geneva, Switzerland, 1989.

79. Malchaire, J.; Piette, A.; Kampmann, B.; Mehnert, P.; Gebhard, H.; Havenith, G.; Den hartog, E.; Holmer, I.; Parsons, K.; Alfano, G.; et al. Development and Validation of the Predicted Heat Strain Model. Ann. Occup. Hyg. 2001, 45, 123-135. [CrossRef]

80. Moran, D.S.; Pandolf, K.B.; Shapiro, Y.; Heled, Y.; Shani, Y.; Matthew, W.T.; Gonzales, R.R. An environmental stress index (ESI) as a substitute for the wet bulb globe temperature (WBGT). J. Therm. Biol. 2001, 26, 427-431. [CrossRef] 
81. Wallace, R.F.; Kriebel, D.; Punnett, L.; Wegman, D.H.; Wenger, C.B.; Gardner, J.W.; Gonzalez, R.R. The effects of continuous hot weather training on risk of exertional heat illness. Med. Sci. Sports Exerc. 2005, 37, 84-90. [CrossRef] [PubMed]

82. European Committee for Standardization. EN ISO 11079. Ergonomics of the Thermal Environment-Determination and Interpretation of Cold Stress When Using Required Clothing Insulation (IREQ) and Local Cooling Effects (ISO 11079:2007); European Committee for Standardization: Brussel, Belgium, 2007.

83. Robinson, D.; Haldi, F. Model to predict overheating risk based on an electrical capacitor analogy. Energy Build. 2007, 40, 1240-1245. [CrossRef]

84. Nicol, F.; Hacker, J.; Spires, B.; Davies, H. Suggestion for new approach to overheating diagnostics. In Proceedings of Air Conditioning and the Low Carbon Cooling Challenge; Cumberland Lodge: Windsor, UK, 2008.

85. Brake, D.J.; Bates, G.P. Limiting Metabolic Rate (Thermal Work Limit) as an Index of Thermal Stress. Appl. Occup. Environ. Hyg. 2010, 17, 176-186. [CrossRef]

86. Sakoi, T.; Mochida, T. Concept of the equivalent wet bulb globe temperature index for indicating safe thermal occupational environments. Build. Environ. 2013, 67, 167-178. [CrossRef]

87. D'Ambrosio Alfano, F.R.; Malchaire, J.; Palella, B.I.; Riccio, G. The WBGT index revisited after 60 years of use. Ann. Occup. Hyg. 2014, 58, 955-970.

88. Olesen, B.W.; d'Ambrosio, F.R.; Parsons, K.; Palella, B.I. The creation of a single indicator that allows the evaluation of the perceived thermal stress in a wide range of environmental conditions and physiological activities required numerous attempts. In Proceeding of the 9th Windsor Conference on "Making Comfort Relevant"; Cumberland Lodge: Windsor, UK, 2016.

89. D'Ambrosio Alfano, F.R.; Palella, B.I.; Riccio, G. Notes on the Implementation of the IREQ Model for the Assessment of Extreme Cold Environments. Ergonomics 2013, 56, 707-724. [CrossRef]

90. American Society of Heating, Refrigerating and Air-Conditioning Engineering (ASHRAE). Thermal Environmental Conditions for Human Occupancy; Standard 55-2004; ASHRAE: Atlanta, GA, USA, 2017.

91. Fanger, P.O. Thermal Comfort; Danish Technical Press: Copenhagen, Denmark, 1970.

92. Hamdi, M.; Lachiver, G.; Michaud, F. A new predictive thermal sensation index of human response. Energy Build. 1999, 29, 167-178. [CrossRef]

93. D'Ambrosio Alfano, F.R.; Palella, B.I.; Riccio, G.; Toftum, J. Fifty years of Fanger's equation: Is there anything to discover yet? Int. J. Ind. Ergon. 2018, 66, 157-160. [CrossRef]

94. D'Ambrosio Alfano, F.R.; Olesen, B.W.; Palella, B.I. Povl Ole Fanger's Impact Ten Years Later. Energy Build. 2017, 152, 243-249. [CrossRef]

95. Yang, L.; Yan, H.; Lam, J.C. Thermal comfort and building energy consumption implications-A review. Appl. Energy 2014, 115, 164-173. [CrossRef]

96. De Dear, R.; Brager, G.; Cooper, D. Developing an Adaptive Model of Thermal Comfort and Preference; RP-884, Final Report; ASHRAE: Berkeley, CA, USA, 1997.

97. Beccali, M.; Nucara, A.; Rizzo, G. Thermal Comfort. In The Encyclopaedia of Energy; Cutler, J.C., Ed.; Elsevier Science: Amsterdam, The Netherlands, 2004; pp. 55-64. ISBN 0-12-176480-X.

98. De Dear, R.J.; Akimoto, T.; Arens, E.A.; Brager, G.; Candido, C.; Cheong, K.W.D.; Li, B.; Nishihara, N.; Sekhar, S.C.; Tanabe, S. Progress in Thermal Comfort Research over the Last Twenty Years. Indoor Air 2013, 23, 442-461. [CrossRef] [PubMed]

99. Haldane, J.S. The influence of high air temperature. Hygiene 1905, 5, 494-513.

100. Hill, L.; Griffith, O.W.; Flack, M. The measurement of the rate of heat-loss at body temperature by convection, radiation, and evaporation. Philos. Trans. Res. Soc. Lond. B 1916, 207, 183-220. [CrossRef]

101. Vernon, H.M. The measurements of radiant heat in relation to human comfort. Proceeding of the Physiological Society. J. Physiol. 1930, 70. [CrossRef]

102. Gagge, A.P.; Rapp, G.M.; Hardy, J.D. Effective radiant field and operative temperature necessary for comfort with radiant heating. Ashrae Trans. 1967, 73, 2.1-2.9.

103. Hevener, O.F. All about humiture. Weatherwise 1959, 12, 56-85. [CrossRef]

104. Craig, F.N. Relation between heat balance and physiological strain in walking men clad in ventilated impermeable. Fed. Proc. 1950, 9, 26.

105. Lind, A.R.; Hallon, R.F. Assessment of physiologic severity of hot climate. J. Appl. Physiol. 1957, 11, 35-40. [CrossRef]

106. Thom, E.C. The discomfort index. Weatherwise 1959, 12, 57-61. [CrossRef] 
107. Tennenbaum, J.; Sohar, E.; Adar, R.; Gilat, T.; Yaski, D. The physiological significance of the cumulative discomfort index (Cum DI). Harefuah 1961, 60, 315-319. [PubMed]

108. Hall, J.F.K.; Polte, W. Physiological index of strain and body heat storage in hyperthermia. J. Appl. Physiol. 1960, 15, 1027-1030. [CrossRef] [PubMed]

109. Lee, D.H.K.; Henschel, A. Evaluation of Thermal Environment in Shelters, Department of Health, Education and Welfare; Public Health Service, Division of Occupational Health: Washington, DC, USA, 1963.

110. Nieuwolt, S. Tropical Climatology: An Introduction to the Climates of the Low Latitudes; John Wiley and Sons: London, UK, 1977.

111. Masterton, J.M.; Richardson, F.A. Humidex, a Method of Quantifying Human Discomfort Due to Excessive Heat and Humidity; Environment Canada: Ottawa, ON, Canada, 1979.

112. Weiss, M. The humisery and other measures of summer discomfort. Nat. Wea. Dig. 1982, 7, 10-18.

113. Pepi, W.J. The Summer Simmer Index. Weatherwise 1987, 40. [CrossRef]

114. Moran, D.S.; Shapiro, Y.; Epstein, Y.; Matthew, W.; Pandolf, K.B. A Modified Discomfort Index (MDI) as an Alternative to the Wet Bulb Globe Temperature (WBGT). In Environmental Ergonomics VIII, Proceedings of the 8th International Conference on Environmental Ergonomics, 18-23 October 1998, San Diego, CA, USA; Naval Health Research Center and San Diego State University: San Diego, CA, USA, 1998; pp. 77-80.

115. Pepi, W.J. The New Summer Simmer Index. In Proceedings of the 80th Annual Meeting of the AMS, Long Beach, CA, USA, 9-14 January 2000.

116. Chartered Institution of Building Services Engineers. CIBSE Guide a Chapter 1: Environmental Criteria for Design; CIBSE: London, UK, 2006.

117. Talaia, M.; Simoes, H. EsConTer: Um índice de avaliaçao de ambiente termico. In Proceedings of the $V$ Congresso Cubano de Meteorologia, Somet-Cuba; Sociedade de Meteorologia de Cuba: La Havana, Cuba, 2009; pp. 1612-1626.

118. Borgeson, S.; Brager, G.S. Comfort standards and variations in exceedance for mixed-mode buildings. Build. Res. Inf. 2010, 39, 118-133. [CrossRef]

119. Houghton, F.C.; Yaglou, C.P. Determining equal comfort lines. Am. Soc. Heat. Vent. Eng. 1923, $29,165-176$.

120. Dufton, A.F. The eupatheostat. Sci. Instrum. 1929, 6, 249-251. [CrossRef]

121. Vernon, H.M.; Warner, C.G. The influence of the humidity of the air on capacity for work at high temperature. Hygiene 1932, 32, 431-463. [CrossRef]

122. Gagge, A.P. Man, his environment, his comfort. Heat. Pip. Air Cond. 1969, 41, 209-224.

123. Winslow, C.E.A.; Herrington, L.P.; Gagge, A.P. Physiological reactions and sensations of pleasantness under varying atmospheric conditions. Trans. Ashve 1937, 44, 179-196.

124. Ionides, M.; Plummer, J.; Siple, P.A. The thermal acceptance ratio. Interm. report No. 1, Climatology and envelope. Fed. Proc. 1945, 9, 26.

125. Bedford, T. Environmental Warmth and Its Measurement; H.M.S.O: London, UK, 1946.

126. Missenard, A. A thermique des ambiences: Équivalences de passage, équivalences de séjours. Chal. Indust 1948, 276, 159-172.

127. Webb, C.G. An analysis of some observations of thermal comfort in an equatorial climate. Brit. J. Ind. Med. 1959, 16, 297-310. [CrossRef] [PubMed]

128. Sohar, E.; Tennenbaum, D.J.; Robinson, N. A Comparison of the Cumulative Discomfort Index (Cum DI) and Cumulative Effective Temperature (Cum ET), as Obtained by Meteorological Data; Tromp, S.W., Ed.; Biometeorology, Pergamon Press: Oxford, UK, 1962; pp. 395-400.

129. Gagge, A.P.; Stolwijk, A.; Nishi, Y. An effective temperature scale based on a simple model of human physiological regulatory response. Ashrae Trans. 1971, 77, 247-257.

130. Nishi, Y.; Gagge, A.P. Humid operative temperature. A biophysical index of thermal sensation and discomfort. J. Physiol. 1971, 63, 365-368.

131. Steadman, R.G. Indices of wind chill of clothed persons. J. Appl. Meteor. 1971, 10, 674-683. [CrossRef]

132. Gonzalez, R.R.; Nishi, Y.; Gagge, A.P. Experimental evaluation of standard effective temperature: A new biometeorological index of man's thermal discomfort. Int. J. Biometeorol. 1974, 18, 1-15. [CrossRef]

133. Steadman, R.G. The Assessment of Sultriness. Part I: A Temperature-Humidity Index Based on Human Physiology and Clothing Science. J. Appl. Meteor. 1979, 18, 861-873. [CrossRef]

134. Wray, W.O. A simple procedure for assessing thermal comfort in passive solar heated buildings. Sol. Energy 1980, 25, 327-333. [CrossRef] 
135. Gagge, A.P.; Fobelets, A.P.; Berglund, L.G. A standard predictive index of human response to the thermal environment. Ashrae Trans. 1986, 92, 709-731.

136. Bureau of Indian Standards. Handbook of Functional Requirements of Buildings (Other than Industrial Buildings); Bureau of Indian Standards: New Delhi, India, 1987.

137. Guide, J. Weather, Solar and Illuminance Data, Chartered Institution of Building Services Engineers; CIBSE: London, UK, 2002; Volume 8.

138. International Standard Organization (ISO). 7730: Ergonomics of the Thermal Environment-Analytical Determination and Interpretation of Thermal Comfort Using Calculation of the PMV and PPD Indices and Local Thermal Comfort Criteria, 3rd ed.; ISO: Geneva, Switzerland, 2005.

139. World Health Organizzation (WHO). WHO Air Quality Guidelines for Particulate Matter, Ozone, Nitrogen Dioxide and Sulfur Dioxide; Summary of Risk Assessment; WHO: Geneva, Switzerland, 2005.

140. Norhidayah, A.; Lee, C.K.; Azhar, M.K.; Nurulwahida, S. Indoor air quality and sick building syndrome in three selected buildings. Procedia Eng. 2013, 53, 93-98. [CrossRef]

141. Yang, J.; Pantazaras, A.; Chaturvedi, K.A.; Chandran, A.K.; Santamouris, M.; Lee, S.E.; Tham, K.W. Comparison of different occupancy counting methods for single system-single zone applications. Energy Build. 2018, 172, 221-234. [CrossRef]

142. Sekhar, C.; Anand, P.; Schiavon, S.; Tham, K.W.; Cheong, D.; Saber, E.M. Adaptable cooling coil performance during part loads in the tropics-A computational evaluation. Energy Build. 2018, 159, 148-163. [CrossRef]

143. Bluyssen, P.M. Towards an integrative approach of improving indoor air quality. Build. Environ. 2009, 44, 1980-1989. [CrossRef]

144. Jansz, J. Sick Building Syndrome. In International Encyclopedia of Public Health, 2nd ed.; Academic Press: Cambridge, MA, USA, 2017; pp. 502-505.

145. Crook, B.; Burton, N.C. Indoor moulds, Sick Building Syndrome and building related illness. Fungal Biol. Rev. 2010, 24, 106-113. [CrossRef]

146. U.S. Environmental Protection Agency (EPA). Guidelines for Ecological Risk Assessment. Federal Register 63. pp. 26846-26924. Available online: https://www.epa.gov/sites/production/files/2014-11/documents/eco_ risk_assessment1998.pdf (accessed on 16 February 2019).

147. World Health Organization. The Right to Healthy Indoor Air. In Proceedings of the WHO Meeting, Bilthoven, The Netherlands, 15-17 May 2000.

148. World Health Organization. Health 21-An Introduction to the Health for all Policy Framework for the WHO European Region: European Health for all Series No 5; World Health Organization Europe Regional Office: Copenhagen, Denmark, 2000.

149. World Health Organization (WHO). Air Pollution: Fifth Report of the Expert Committee on Environmental Sanitation; WHO Technical Report Series, No. 157; World Health Organization: Geneva, Switzerland, 1958; Available online: http://apps.who.int/iris/handle/10665/40416 (accessed on 6 December 2018).

150. World Health Organization (WHO). Atmospheric Pollutants: Report of a WHO Expert Committee; WHO Technical Report Series, No. 271; World Health Organization: Geneva, Switzerland, 1964; Available online: http://apps.who.int/iris/handle/10665/40578 (accessed on 6 December 2018).

151. World Health Organization (WHO). Air Quality Criteria and Guides for Urban Air Pollutants: Report of a WHO Expert Committee; WHO Technical Report Series, No. 506; World Health Organization: Geneva, Switzerland, 1972; Available online: http://apps.who.int/iris/handle/10665/40989 (accessed on 6 December 2018).

152. World Health Organization (WHO). Regional Office for Europe; Air Quality Guidelines for Europe; World Health Organization Europe Regional Office: Copenhagen, Denmark, 1987.

153. World Health Organization (WHO). Air Quality Guidelines for Europe. Second Edition; European Health for all Series No 91; World Health Organization Europe Regional Office: Copenhagen, Denmark, 2000.

154. European Commission. Council directive 96/62/EC of 27 September 1996 on Ambient Air Quality Assessment and Management 96/62/EC. Available online: https://eur-lex.europa.eu/legal-content/EN/TXT/?uri=CELEX\% 3A31996L0062 (accessed on 10 January 2020).

155. World Health Organization (WHO) Regional Office for Europe. Air Quality Guidelines; Global Update; WHO: Geneva, Switzerland, 2005.

156. World Health Organization (WHO) Regional Office for Europe. WHO Guidelines for Indoor Air Quality: Dampness and Mould; World Health Organization Europe Regional Office: Copenhagen, Denmark, 2009. 
157. World Health Organization (WHO) Regional office for Europe. Selected Pollutants: Who Guideline for Indoor Air Quality; World Health Organization Europe Regional Office: Copenhagen, Denmark, 2010.

158. World Health Organization (WHO) Regional office for Europe. Indoor Air Quality Guidelines: Household Fuel Combustion; World Health Organization Europe Regional Office: Copenhagen, Denmark, 2014.

159. American Society of Heating, Refrigerating and Air-Conditioning Engineering (ASHRAE). Indoor Air Guide; Environmental Protection Agency: Atlanta, GA, USA, 2009.

160. Anand, P. Development of a Data-Driven Occupancy-Based Building Energy and IEQ Model. Ph.D. Thesis, National University of Singapore, Singapore, 2019.

161. American Society of Heating, Refrigerating and Air-Conditioning Engineering (ASHRAE). Ventilation and Acceptable Indoor Air Quality; ANSI/ASHRAE standard 62.1; ASHRAE: Atlanta, GA, USA, 2013.

162. Fanger, P.O. Introduction of the olf and the decipol Units to Quantify Air Pollution Perceived by Humans Indoors and Outdoors. Energy Build. 1987, 12, 1-6. [CrossRef]

163. Cohas, M. Ventilation et Qualité de l'Air dans l'Habitat, 5th ed.; Les éditions Parisiennes (EDIPA): Paris, France, 1996.

164. Kirchner, S.; Jedor, B.; Mandin, C. Elaboration D'indices de la Qualite de L'Air Interieur: Phase 1: Inventaire des Indices Disponibles. 2015. Available online: http://www.oqai.fr/userdata/documents/483_Inventaire_ OQAI_Indices_2006.pdf (accessed on 9 February 2019).

165. Indoor Air Quality Management Group. A Guide on Indoor Air Quality Certification Scheme for Offices and Public Places. 2015. Available online: http://www.iaq.gov.hk/en/publications-and-references/guidance-notes. aspx (accessed on 9 February 2019).

166. Chiang, C.M.; Lai, C.M. A study on the comprehensive indicator of indoor environment assessment for occupants' health in Taiwan. Build. Environ. 2002, 37, 387-392. [CrossRef]

167. Moschandreas, D.; Sofuoglu, S.C. The indoor air pollution index. Indoor Air 1999, 99, 261-266.

168. Moschandreas, D.J.; Sofuoglu, S.C. The indoor environmental index and its relationship with symptoms of office building occupants. J. Air Waste Manag. Assoc. 2004, 54, 1440-1451. [CrossRef]

169. Rojas, G.; Pfluger, R.; Feist, W. Ventilation concepts for energy efficient housing in Central European climate-A simulation study comparing IAQ, mold risk and ventilation losses. In Proceedings of the 14th International Conference on Indoor Air Quality and Climate, Indoor Air 2016, Ghent, Belgium, 3-8 July 2016.

170. Gadeau, A.L. Assessment of ventilation strategies using an air quality index introduced in CLIM 2000 software, Espoo, Finland. Proc. Healthy Build. 1996, 4, 23-24.

171. Castanet, S. Contribution À L'étude de la Ventilation Et de la Qualité de L'air Intérieur des Locaux. Ph.D. Thesis, INSA, Lyon, France, 1998.

172. QUAD-BBC. Choix de Paramètres de Suivi de la Qualité de L'air Intérieur; Report T1.2 for the project QUAD-BBC; International Energy Agency: Paris, France, 2012.

173. Sofuoglu, S.C.; Moschandreas, D.J. The link between symptoms of office building occupants and in-office air pollution: The Indoor Air Pollution Index. Indoor Air 2003, 13, 332-343. [CrossRef] [PubMed]

174. Marchand, D.; Belair, F.; Kirchner, S. Indices de qualité d'air intérieur: Vers une culture du risque sanitaire. Environnement Risques \& Santé 2008, 7, 341-347.

175. Teichman, K.; Howard-Reed, C.; Persily, A.; Emmerich, S. Characterizing Indoor Air Quality Performance Using a Graphical Approach; NIST: Gaithersburg, MD, USA, 2016.

176. Logue, J.M.; Price, P.N.; Sherman, M.H.; Singer, B.C. A method to estimate the chronic health impact of air pollutants in U.S. residences. Environ. Health Perspect. 2010, 120, 216-222. [CrossRef]

177. Luo, N.; Weng, W.; Xu, X.; Hong, T.; Fu, M.; Su, K. Assessment of occupant-behavior based indoor air quality and its impacts on human exposure risk: A case study based on the wildfires in Northern California. Sci. Total Environ. 2019, 686, 1251-1261. [CrossRef]

178. Wei, W.; Ramalho, O.; Derbez, M.; Riberon, J.; Kirchner, S.; Mandin, C. Applicability and relevance of six indoor air quality indexes. Build. Environ. 2016, 109, 42-49.

179. van Dijken, F.; Boerstra, A.C. The ABCD Tool for schools. In Proceedings of the 9th International Conference and Exhibition on Healthy Buildings 2009, Syracuse, NY, USA, 13-17 September 2009.

180. Environment Protection Agency. Indoor AirPLUS Construction Specifications Version 1 (Rev 03) USA, 2015. Available online: http://www2.epa.gov/sites/production/files/2015-10/documents/construction_specification_ rev_3_508.pdf (accessed on 16 February 2019). 
181. Cony, L.R.S.; Abadie, M.; Wargocki, P.; Rode, C. Towards the definition of indicators for assessment of indoor air quality and energy performance in low-energy residential buildings. Energy Build. 2017, 152, 492-502. [CrossRef]

182. Zhu, C.; Li, N. Study on indoor air quality evaluation index based on comfort evaluation experiment. Energy Procedia 2017, 205, 2246-2253. [CrossRef]

183. Energy in Building and Community programme (EBC) and International Energy Agency (IEA) Indoor Air Quality Design and Control in Low Energy Residential Buildings IEA EBC Annex 68 2015. Available online: http://www.iea-ebc-annex68.org/about_annex-68 (accessed on 8 November 2018).

184. Reinten, J.; Braat-Eggen, P.E.; Hornikx, M.; Kort, H.S.M.; Kohlrausch, A. The indoor sound environment and human task performance: A literature review on the role of room acoustics. Build. Environ. 2017, 123, 315-332. [CrossRef]

185. Health and Safety Executive (HSE). Controlling Noise at Work. The Control of Noise at Work, 2nd ed.; HSE Books: Sudbury, Suffolk, UK, 2005; ISBN 978-0-7176-6164-4.

186. Directive 2003/10/EC of the European Parliament and of the Council of 6 February 2003 on the Minimum Health and Safety Requirements Regarding the Exposure of Workers to the Risks Arising from Physical Agents (Noise) (Seventeenth Individual Directive within the Meaning of Article 16 of Directive 89/391/EEC), OJ L 42, 15.2.2003. Available online: https://eur-lex.europa.eu/legal-content/EN/ALL/?uri=CELEX\%3A32003L0010 (accessed on 10 January 2020).

187. International Organization for Standardization ISO 9612. Acoustics-Determination of Occupational Noise Exposure-Engineering Method; ISO: Geneva, Switzerland, 2009.

188. Leccese, F.; Salvadori, G.; Rocca, M.; Spinelli, N. Risk assessment of noise exposure in a machine shop and choice of hearing protection equipment. G Ital. Med. Lav. Ergon. 2016, 38, 5-13.

189. European Environment Agency. Good Practice Guide on Noise Exposure and Potential Health Effects; EEA Technical Report no. 11/2010; European Environment Agency: Copenhagen, Denmark, 2010.

190. World Health Organization. Night Noise Exposure Guidelines for Europe; WHO Regional Office for Europe: Copenhagen, Denmark, 2009; Available online: http://www.euro.who.int/_data/assets/pdf_file/0017/43316/ E92845.pdf (accessed on 6 June 2019).

191. Al horr, Y.; Arif, M.; Katafygiotou, M.; Mazroei, A.; Kaushik, A.; Elsarrag, E. Impact of indoor environmental quality on occupant well-being and comfort: A review of the literature. Int. J. Sustain. Built Environ. 2016, 5, 1-11. [CrossRef]

192. Navai, M.; Veitch, J.A. Acoustic Satisfaction in Open-Plan Offices: Review and Recommendations, Research Report RR-151; Institute for Research in Construction, National Research Council Canada: Ottawa, ON, Canada, 2003; Available online: http://www.nrc-cnrc.gc.ca/obj/irc/doc/pubs/rr/rr151/rr151.pdf (accessed on 12 February 2019).

193. Choi, Y.J. Effect of occupancy on acoustical conditions in university classrooms. Appl. Acoust. 2016, 114, 36-43. [CrossRef]

194. Bistafa, S.R.; Bradley, J.S. A Comparative study of Speech Intelligibility Metrics and the Derivation of Optimum Reverberation Time and Maximum Background-Noise Level for Classrooms; Institute of Research in Construction, National Research Council Canada: Ottawa, ON, Canada, 1999.

195. Nowoświat, A.; Olechowska, M. Fast estimation of speech transmission index using the reverberation time. Appl. Acoust. 2016, 102, 55-61. [CrossRef]

196. Leccese, F.; Rocca, M.; Salvadori, G. Fast estimation of Speech Transmission Index using Reverberation Time: Comparison between predictive equations for educational rooms of different sizes. Appl. Acoust. 2018, 140, 143-149. [CrossRef]

197. Beranek, L.L. Balanced noise criterion (NCB) curves. J. Acoust. Soc. Am. 1989, 86, 650-664. [CrossRef]

198. Ayr, U.; Cirillo, E.; Martellotta, F. A new parameter for the assessment of noise annoyance in air-conditioned buildings. In Proceedings of the Clima 2000/Naples 2001 World Congress, Napoli, Italy, 15-18 September 2001.

199. Beranek, L.L.; Blazier, W.E.; Figwer, J.J. Preferred noise criterion (PNC) curves and their application to rooms. J. Acoust. Soc. Am. 1971, 50, 1223-1228. [CrossRef]

200. Kryter, K.D. The Effects of Noise on Man; Academic Press: New York, NY, USA, 1970.

201. Beranek, L.L. Criteria for office quieting based on questionnaire rating studies. J. Acoust. Soc. Am. 1956, 28, 833-852. [CrossRef] 
202. Robinson, D.W. Towards a unified system of noise assessment. J. Acoust. Soc. Am. 1971, 14, $279-298$. [CrossRef]

203. International Organization for Standardization. ISO 1996-1: Acoustics-Description, Measurement and Assessment of Environmental Noise, Part 1: Basic Quantities and Assessment Procedures; ISO: Geneva, Switzerland, 2016.

204. Hay, B.; Kemp, K.F. Measurement of noise in air-conditioned, landscaped offices. J. Sound Vib. 1972, 23, 363-373. [CrossRef]

205. Ayr, U.; Cirillo, E.; Martellotta, F. Further investigations on the definition of a new parameter to assess noise annoyance in air conditioned offices. Energy Build. 2002, 34, 765-774. [CrossRef]

206. Blazier, W.E. Revised noise criterion for application in the acoustical design and rating of HVAC systems. Noise Control Eng. J. 1981, 162, 64-73. [CrossRef]

207. Blazier, W.E. Sound quality consideration in rating noise from heating, ventilating and air-conditioning (HVAC) systems in buildings. Noise Control Eng. J. 1995, 43, 53-63. [CrossRef]

208. Blazier, W.E. RC Mark II: A refined procedure for rating the noise of heating, ventilating, and air-conditioning (HVAC) systems in buildings. Noise Control Eng. J. 1997, 45, 243-250. [CrossRef]

209. Beranek, L.L. The Design of Speech Communication Systems. In Proceedings of the IRE; IEEE: Piscataway, NJ, USA, 1947; Volume 35, pp. 880-890.

210. Stevens, S. Procedure for calculating loudness: Mark IV. J. Acoust. Am. Soc. 1983, 33, 1577-1585. [CrossRef]

211. International Organization for Standardization. ISO 532-1: Acoustics-Methods for Calculation Loudness, Part 1-Zwicker method; ISO: Geneva, Switzerland, 2017.

212. French, N.R.; Steinberg, J.C. Factors governing the intelligibility of speech sounds. J. Acoust. Am. Soc. 1947, 19, 90-119. [CrossRef]

213. Peutz, V.M. A Articulation Loss of Consonants as a Criterion for Speech Transmission in a Room. J. Audio Eng. Soc. 1971, 19, 915-919.

214. Reichardt, W.; Abdel Alim, O.; Schmidt, W. Definition und Messgrundlage eines objektiven Masses zur Ermittlung der Grenze zwischen brauchbarer und unbrauchbarer Durchsichtigkeit beim Musikdarbietung. Acustica 1975, 32, 126-137.

215. Thiele, R. Die Richtungsverteilung und Zeitfolge der Schallrückwürfe in Räumen (Directional distribution and time sequence of sound reflections in rooms). Acta Acust. United Acust. 1953, 3, 291-302.

216. Jordan, V.L. A comprehensive Musical Criterion: The inversion Index. In Proceedings of the 47th Audio Engineering Society Convention, Copenhagen, Denmark, 26-29 March 1974.

217. Cremer, L.; Muller, H. Principles and Applications of Room Acoustics vol. 1 \& 2; English translation with additions by T. Schultz.; Applied Science Publishers: New York, NY, USA, 1982.

218. Dammerud, J.J.; Barron, M.; Kahle, E. Objective Assessment of Acoustic Conditions for Symphony Orchestras. Build. Acoust. 2011, 18, 207-219. [CrossRef]

219. Sabine, W.C. Collected Papers on Acoustics; Reprinted by Dover; University Press Harvard: New York, NY, USA, 1964.

220. Eyring, C.F. Reverberation time in "Dead" rooms. J. Acoust. Soc. Am. 1930, 26, 217-241. [CrossRef]

221. Arau-Puchades, H. An Improved Reverberation Formula. Acta Acust. 1988, 65, 163-180.

222. Millington, G. A modified formula for reverberation. J. Acoust. Soc. Am. 1932, 4, 69-82. [CrossRef]

223. IEC 60268-16. In Sound System Equipment. Part 16: Objective Rating of Speech Intelligibility by Speech Transmission Index, 4th ed.; IEC: Geneva, Switzerland, 2011.

224. Pelegrin Garcia, D.; Brunkoq, J.; Lyberg-Ahlander, V.; Lofquist, A. Measurement and prediction of voice support and room gain in school classroom. J. Acoust. Soc. Am. 2012, 131, 194-204. [CrossRef] [PubMed]

225. Latham, H.G. The signal-to-noise ratio for speech intelligibility-An auditorium acoustics design index. Appl. Acoust. 1979, 12, 253-320. [CrossRef]

226. American National Standards Institute (ANSI). Methods for Calculation of the Speech Intelligibility Index; ANSI/ASA S3.5-1997 (R2017); ANSI: Washington, DC, USA, 2017.

227. Houtgast, T.; Steeneken, H.J.M.; Plomp, R. Predicting speech intelligibility in rooms from the modulation transfer function. I. General room acoustics. Acustica 1980, 46, 60-72.

228. Van Wijngaarden, S.; Verhave, J.; Steeneken, H. The speech transmission index after four decades of development. Acoust. Aust. 2012, 40, 134-138. 
229. Barron, M.; Lee, L.J. Energy relations in concert auditoriums. I J. Acoust. Soc. Am. 1988, 84, 618-628. [CrossRef]

230. Pelegrín-García, D. Comment on 'Increase in voice level and speaker comfort in lecture rooms'. J. Acoust. Soc. Am. 2011, 129, 1161.

231. Cotana, F.; Goreti, M. Acoustic classification of Buildings: Impact of acoustic performances of high acoustic performance of a high energy-efficient building on quality and sustainability indicators. In Proceedings of the 20th International Congress on Acoustics, ICA 2010, Sydney, Australia, 23-27 August 2010.

232. European Committee for Standardization. EN 12354-5 Building Acoustics-Estimation of Acoustic Performance of Buildings from the Performance of Elements_Part 5: Sounds Levels Due to the Service Equipment; European Committee for Standardization: Brussels, Belgium, 2000.

233. European Committee for Standardization. EN 12354-2 Building Acoustics-Estimation of Acoustic Performance of Buildings from the Performance of Elements-Part 2: Impact Sound Insulation Between Rooms; European Committee for Standardization: Brussels, Belgium, 2000.

234. European Committee for Standardization. EN 12354-1 Building Acoustics-Estimation of Acoustic Performance of Buildings from the Performance of Elements-Part 1: Airborne Sound Insulation Between Rooms; European Committee for Standardization: Brussels, Belgium, 2000.

235. European Committee for Standardization. EN 12354-3 Building Acoustics-Estimation of Acoustic Performance of Buildings from the Performance of Elements_Part 3: Airborne Sound Insulation Against Outdoor Sound; European Committee for Standardization: Brussels, Belgium, 2000.

236. Yang, D.; Mak, C.M. An assessment model of classroom acoustical environment based on fuzzy comprehensive evaluation method. Appl. Acoust. 2017, 127, 292-296. [CrossRef]

237. Madbouly, A.I.; Noaman, A.Y.; Ragab, A.H.M.; Khedra, A.; Fayoumi, A.G. Assessment model of classroom acoustics criteria for enhancing speech intelligibility and learning quality. Appl. Acoust. 2016, 114, 147-158. [CrossRef]

238. Boyce, P.R. Human Factors in Lighting, 2nd ed.; Taylor and Francis: London, UK, 1981.

239. International Well Building Institute. WELL Building Standard. Available online: https://www.wellcertified. com/ (accessed on 6 June 2019).

240. Heiden, M.; Zetterberg, C.; Lindberg, P.; Nylen, P.; Hemphala, H. Validity of a computer-based risk assessment method for visual ergonomics. Int. J. Ind. Ergon. 2019, 72, 180-187. [CrossRef]

241. Leccese, F.; Salvadori, G.; Rocca, M. Visual discomfort among university students who use CAD workstations. Work 2016, 55, 171-180. [CrossRef] [PubMed]

242. Taino, G.; Ferrari, M.; Mestad, I.J.; Fabris, F.; Imbriani, M. Astenophia and work at VDT: Study on a population of 191 workers exposed to risk through administering of anamnestic questionnaire focused on ophthalmic assessment. G. Ital. Med. Lav. Ergon. 2006, 34, 487-497.

243. Leccese, F.; Salvadori, G.; Montagnani, C.; Ciconi, A.; Rocca, M. Lighting assessment of ergonomic workstation for radio diagnostic reporting. Int. J. Ind. Ergon. 2017, 57, 42-54. [CrossRef]

244. Yan, Z.; Hu, L.; Chen, H.; Lu, F. Computer Vision Syndrome: A widely spreading but largely unknown epidemic among computer users. Comput. Hum. Behav. 2008, 24, 2026-2042. [CrossRef]

245. Bergqvist, U. Visual Display Terminal work-A perspective on long-term changes and discomfort. Int. J. Ind. Ergon. 1995, 16, 201-209. [CrossRef]

246. Turville, K.L.; Psihogios, J.P.; Ulmer, T.R.; Mirka, G.A. The effects of video display terminal height on the operator: A comparison of the $15^{\circ}$ and $40^{\circ}$ recommendations. Appl. Ergon. 1998, 29, 239-246. [CrossRef]

247. Pillastrini, P.; Mugnaia, R.; Bertozzi, L.; Costi, S.; Curti, S.; Guccione, A.; Mattioli, S.; Violante, F.S. Effectiveness of an ergonomic intervention on work-related posture and low back pain in video display terminal operators: A 3 year cross-over trial. Appl. Ergon. 2010, 41, 436-443. [CrossRef]

248. Mirmohammadi, S.J.; Mehrparvar, A.H.; Olia, M.B.; Mirmohammadi, M. Effects of training intervention on non-ergonomic positions among video display terminals (VDT) users. Work 2012, 42, 429-433. [CrossRef]

249. Powell, A.L. Computer anxiety: Comparison of research from the 1990s and 2000s. Comput. Hum. Behav. 2013, 29, 2337-2381. [CrossRef]

250. Leccese, F.; Salvadori, G.; Rocca, M. Visual ergonomics of video-display-terminal workstations: Field measurements of luminance for various display settings. Displays 2016, 42, 9-18. [CrossRef] 
251. Lin, Y.T.; Lin, P.H.; Hwang, S.L.; Jeng, S.C.; Liao, C.C. Investigation of legibility and visual fatigue for simulated flexible electronic paper under various surface treatments and ambient illumination conditions. Appl. Ergon. 2009, 40, 922-928. [CrossRef] [PubMed]

252. Blehm, C.; Vishnu, S.; Khattak, A.; Mitra, S.; Yee, R.W. Computer vision syndrome: A review. Surv. Ophthalmol. 2005, 50, 253-262. [CrossRef] [PubMed]

253. Helland, M.; Horgen, G.; Kvikstad, T.R.; Garthus, T.; Bruenech, J.R.; Aaras, A. Musculoskeletal, visual and psychosocial stress in VDU operators after moving to an ergonomically designed office landscape. Appl. Ergon. 2008, 39, 284-295. [CrossRef]

254. Wilkins, A.J.; Evans, B. Visual stress, its treatment with special filters, and its relationship to visually induced motion sickness. Appl. Ergon. 2010, 41, 509-515. [CrossRef]

255. Pinto, I.; Brogi, A.; Piccolo, F.; Stacchini, N.; Buonocore, G.; Bellieni, C. Blue Light and Ultraviolet Radiation Exposure from infant Phototherapy Equipment. J. Occup. Environ. Hyg. 2015, 12, 603-610. [CrossRef]

256. Directive 89/654/EEC of the European Parliament and of the Council of 30 November 1989 Concerning the Minimum safety and Health Requirements for the Workplace. Available online: https:/eur-lex.europa.eu/ legal-content/EN/TXT/?uri=CELEX\%3A31989L0654 (accessed on 10 January 2020).

257. Directive 2006/25/EC of the European Parliament and of the Council of 5 April 2006 on the Minimum Health and Safety Requirements regarding the Exposure of Workers to Risks Arising from Physical Agents (Artificial Optical Radiation). Available online: https:/eur-lex.europa.eu/legal-content/EN/TXT/?uri= CELEX\%3A02006L0025-20140101 (accessed on 10 January 2020).

258. Leccese, F.; Salvadori, G.; Casini, M.; Bertozzi, M. Analysis and measurements of artificial optical radiation (AOR) emitted by lighting sources found in offices. Sustainability 2014, 6, 5941-5954. [CrossRef]

259. European Commission. Council directive 96/62/EC of 27 September 1996 on ambient air quality assessment and management 96/62/EC. Available online: https:/osha.europa.eu/en/legislation/guidelines/non-bindingguide-to-good-practice-for-implementing-directive-2006-25-ec-201aartificial-optical-radiation2019 (accessed on 7 January 2020).

260. Leccese, F.; Vandelanotte, V.; Salvadori, G.; Rocca, M. Blue light hazard and risk group classification of 8 W LED tubes, replacing fluorescent tubes, through optical radiation measurements. Sustainability 2015, 7, 13454-13468. [CrossRef]

261. International Commission on Non-Ionizing Radiation Protection. ICNIRP Guidelines on limits of exposure to incoherent visible and infrared radiation. Health Phys. 2013, 105, 74-96.

262. International Commission on Non-Ionizing Radiation Protection. ICNIRP Guidelines on limits of exposure to ultraviolet of wavelength between $180 \mathrm{~nm}$ and $400 \mathrm{~nm}$ (incoherent optical radiation). Health Phys. 2004, 87, 171-186. [CrossRef]

263. European Committee for Standardization. Photobiological Safety of Lamps and Lamp Systems; EN 62471; European Committee for Standardization: Bruxelles, Belgium, 2009.

264. International Electrotechnical Commission. Application of IEC 62471 for the Assessment of Blue Light Hazard to Light Sources and Luminaires; IEC/TR 62778:2012; International Electrotechnical Commission: Geneva, Switzerland, 2014.

265. European Committee for Electrotechnical Standardization. Light and Lighting-Basic Terms and Criteria for Specifying Lighting Requirements; EN 12665; European Committee for Electrotechnical Standardization: Bruxelles, Belgium, 2018.

266. European Committee for Standardization. Light and Lighting_Lighting of Work Places_Part 1: Indoor Work Places; EN 12464-1; European Committee for Standardization: Brussels, Belgium, 2011.

267. Berman, S.M. Energy Efficiency Consequences of Scotopic Sensitivity. J. Illum. Eng. Soc. 1992, $21,3-14$. [CrossRef]

268. Thornton, W.A. Color-discrimination index. J. Opt. Soc. Am. 1972, 62, 191-194. [CrossRef] [PubMed]

269. Thornton, W.A. A validation of the color preference index. J. Illum. Eng. Soc. 1974, 4, 48-52. [CrossRef]

270. Xu, H. Color-rendering capacity of illumination. J. Opt. Soc. Am. 1983, 73, 1709-1713. [CrossRef]

271. Davis, W.; Ohno, Y. Color quality scale. Opt. Eng. 2010, 49, 336021-3360216. [CrossRef]

272. Hashimoto, K.; Yano, T.; Nayatani, Y. Proposal of practical method for calculating and indexing feeling of contrast for a light source. Illum. Eng. Inst. Jpn. 2000, 84, 843-849. [CrossRef]

273. Judd, D.B. A flattery index for artificial illuminants. Illum. Eng. 1967, 62, 593-598. 
274. Freyssinier-Nova, J.P.; Rea, M.S. A two-metric proposal to specify the color-rendering properties of light sources for retail lighting, in Tenth International Conference of Solid-State Lighting. In Proceedings of the SPIE, San Diego, CA, USA, 23 August 2010.

275. Smet, K.G.; Ryckaert, W.R.; Pointer, M.R.; Deconick, G.; Hanseler, P. Memory color quality metric for white light sources. Energy Build. 2012, 49, 216-225. [CrossRef]

276. Pointer, M.R. Measuring color rendering-A new approach. Light Res. Technol. 1986, 18, 175-184. [CrossRef]

277. Illuminating Engineering Society (IES). Approved Method: IES Spatial Daylight Autonomy (sDA) and Annual Sunlight Exposure (ASE) (IES-LM-83-12); IES: Washington DC, USA, 2012.

278. Rogers, Z.; Goldman, D. Daylighting Metric Development Using Daylight Autonomy Calculations in the Sensor Placement Optimization Tool-Development Report and Case Studies; Architectural Energy Corporation: Boulder, CO, USA, 2006.

279. Reinhart, C.; Walkenhorst, O. Validation of dynamic RADIANCE-based daylight simulations for a test office with external blinds. Energy Build 2001, 33, 683-697. [CrossRef]

280. Walsh, J.W.T. The early years of Illuminating engineering in Great Britain. Trans. Illum. Eng. Soc. 1951, 15, 49-60. [CrossRef]

281. Sicurella, F.; Evola, G.; Wurtz, E. A statistical approach for the evaluation of thermal and visual comfort in free-running buildings. Energy Build 2012, 47, 402-410. [CrossRef]

282. Nabil, A.; Mardaljevic, J. Useful daylight illuminances: A replacement for daylight factors. Energy Build 2006, 38, 905-913. [CrossRef]

283. Einhorn, H.D. Discomfort glare: A formula to bridge differences. Lighting Res. Technol. 1979, 11, 90-94. [CrossRef]

284. International Commission on Illumination. Glare from Small, Large and Complex Sources (CIE 147); International Commission on Illumination: Vienna, Austria, 2002.

285. Guth, S.K. A method for the evaluation of discomfort glare. Illum. Eng. 1963, 57, 351-364.

286. Nazzal, A. A new evaluation method for daylight discomfort glare. Int. J. Ind. Ergon. 2005, 35, $295-306$. [CrossRef]

287. Wienold, J. Dynamic daylight glare evaluation. In Proceedings of the 11th International IBPSA Conference, Building Simulation, Glasgow, UK, 27-30 July 2009; pp. 944-951.

288. International Commission on Illumination. Equations for Disability Glare (CIE 146); International Commission on Illumination: Vienna, Austria, 2002.

289. Hviid, C.; Nielsen, T.; Svendsen, S. Simple tool to evaluate the impact of daylight on building energy consumption. Sol. Energy 2008, 82, 787-798. [CrossRef]

290. Meyer, J.J. Visual discomfort: Evaluation after introducing modulated light equipment. In Proceedings of the 2nd European Conference on Energy-Efficient Lighting, in Right Light, Arnhem, NL, 26-29 September 1993; pp. 348-357.

291. Chauvel, P.; Collins, J.B.; Dogniaux, R.; Longmore, J. Glare from windows: Current views of the problem. Light. Res. Technol. 1982, 14, 31-46. [CrossRef]

292. Tokura, M.; Iwata, T.; Shukuya, M. Experimental study on discomfort glare caused by windows; development of a method for evaluating discomfort glare from a large light source. J. Arch. Plan Envrion. Eng. 1996, 489, $17-25$.

293. International Commission on Illumination. Discomfort Glare in Interior Lighting (CIE 117); International Commission on Illumination: Vienna, Austria, 1995.

294. Ente Italiano di Normazione. Luce e Illuminazione-Illuminazione di Interni-Valutazione Dell'abbagliamento Molesto con il Metodo UGR (UNI 11165); Ente Italiano di Normazione: Milan, Italy, 2005.

295. Petherbridge, P.; Hopkinson, R.G. Discomfort glare and the lighting of buildings. Trans Illum. Eng. Soc. 1950, 15, 29-79. [CrossRef]

296. Wienold, J.; Christoffersen, J. Towards a new daylight glare rating. In Proceedings of the 10th European Lighting Conference Lux Europa, Berlin, Germany, 19-21 September 2005; pp. 157-161.

297. Bellia, L.; Bisegna, F.; Spada, G. Lighting in indoor environments: Visual and non-visual effects of light sources with different spectral power distributions. Build. Environ. 2010, 46, 1984-1992. [CrossRef]

298. Zeitzer, J.M.; Dijk, D.J.; Kronauer, R.E.; Brown, E.N.; Czeisler, C.A. Sensitivity of the human circadian pacemaker to nocturnal light: Melatonin phase resetting and suppression. J. Physiol. 2000, 526, 695-702. [CrossRef] [PubMed] 
299. Bisegna, F.; Burattini, C.; Li Rosi, O.; Blaso, L.; Fumagalli, S. Non visual effects of light: An overview and an Italian experience. Energy Procedia 2015, 78, 723-728.

300. Rea, M.S. Lighting simply made better: Providing a full range of benefits without much fuss. Build. Environ. 2018, 144, 57-65. [CrossRef]

301. Enezi, J.; Revell, V.; Brown, T.; Wynne, J.; Schlangen, L.; Lucas, R. A “Melanopic" Spectral Efficiency Function Predicts the Sensitivity of Melanopsin Photoreceptors to Polychromatic Lights. J. Biol. Rhythm. 2011, 26, 314-323. [CrossRef]

302. Lucas, R.; Peirson, S.; Berson, D.; Brown, T.; Cooper, H.; Czeisler, C.; Figueiro, M.; Gamlin, P.; Lockley, S.; O'Hagan, J.; et al. Measuring and using light in the melanopsin age. Trends Neurosci. 2014, 37, 1-9. [CrossRef]

303. Lucas Group. Excel-Based Melanopic Illuminance Calculator. University of Manchester. Available online: http://lucasgroup.lab.ls.manchester.ac.uk/research/measuringmelanopicilluminance/ (accessed on 25 February 2019).

304. Rea, M.S.; Figueiro, M.; Bierman, A.; Hamner, R. Modelling the spectral sensitivity of the human circadian system. Light. Res. Technol. 2012, 44, 386-396. [CrossRef]

305. Lighting Research Center. Circadian Stimulus Calculator. Available online: http://www.lrc.rpi.edu/programs/ lightHealth/ (accessed on 25 February 2019).

306. Konis, K. A novel circadian daylight metric for building design and evaluation. Build. Environ. 2017, 113, 22-38. [CrossRef]

307. Chang, A.M.; Santhi, N.; St Hilaire, M.; Gronfier, C.; Bradstreet, D.S.; Duffy, J.F.; Lockley, S.W.; Kronauer, R.E.; Czeisler, C.A. Human responses to bright light of different durations. J. Physiol. 2012, 590, 3103-3112. [CrossRef]

308. Figueiro, M.G.; Gonzales, K.; Pedler, D. Designing with Circadian Stimulus. Des. Appl. 2016, 46, 31-34. Available online: https://www.lrc.rpi.edu/programs/lightHealth/index.asp (accessed on 6 June 2019).

(C) 2020 by the authors. Licensee MDPI, Basel, Switzerland. This article is an open access article distributed under the terms and conditions of the Creative Commons Attribution (CC BY) license (http://creativecommons.org/licenses/by/4.0/). 